\title{
Thermodynamic properties of tin: Part I Experimental investigation, ab-initio modelling of alpha-, beta-phase and a thermodynamic description for pure metal in solid and liquid state from $0 \mathrm{~K}$
}

\author{
A. V. Khvan, T. Babkina, A. T. Dinsdale, I. A. Uspenskaya, I. V. Fartushna, A. I. \\ Druzhinina, A. B. Syzdykova, M. P. Belov and Igor Abrikosov
}

The self-archived postprint version of this journal article is available at Linköping University Institutional Repository (DiVA):

http://urn.kb.se/resolve?urn=urn:nbn:se:liu:diva-158799

N.B.: When citing this work, cite the original publication.

Khvan, A. V., Babkina, T., Dinsdale, A. T., Uspenskaya, I. A., Fartushna, I. V., Druzhinina, A. I., Syzdykova, A. B., Belov, M. P., Abrikosov, I., (2019), Thermodynamic properties of tin: Part I Experimental investigation, ab-initio modelling of alpha-, beta-phase and a thermodynamic description for pure metal in solid and liquid state from o K, Calphad, 65, 50-72.

https://doi.org/10.1016/j.calphad.2019.02.003

Original publication available at:

https://doi.org/10.1016/j.calphad.2019.02.003

Copyright: Elsevier

http://www.elsevier.com/

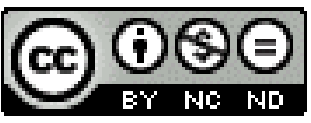

Tweet 
Thermodynamic properties of tin:

Part I Experimental investigation, ab-initio modelling of $\alpha$-, $\beta$-phase and a thermodynamic description for pure metal in solid and liquid state from $0 \mathrm{~K}$

Khvan A.V ${ }^{1)}$, Babkina T ${ }^{2)}$, Dinsdale A.T. ${ }^{3)}$ Uspenskaya I.A. ${ }^{2)}$, Fartushna I V. ${ }^{1)}$, Druzhinina A.I. ${ }^{2)}$, Syzdykova A.B. ${ }^{4}$, Belov M.P. ${ }^{4)}$, Abrikosov I.A. ${ }^{4,5)}$

1) Thermochemistry of materials SRC, NUST MISIS, Leninskiy prosp, 4, 199049 Moscow, Russia

2) Department of Chemistry, Lomonosov Moscow State University, 1-3 Leninskiye Gory, 119991 Moscow, Russia

3) Hampton Thermodynamics Limited, London, UK

4) Materials Modeling and Development Laboratory, NUST MISIS, Leninskiy prospect, 4, 119049 Moscow, Russia

5) Department of Physics, Chemistry and Biology (IFM), Linkoping University, SE-581 83, Linkoping, Sweden

\begin{abstract}
Thermodynamic data for crystalline white and grey tin were assessed using an extended Einstein model from $0 \mathrm{~K}$. Ab-initio simulations in the framework of density functional theory (DFT) with the quasiharmonic approximation (QHA) were carried out to define the heat capacities for both phases of tin from $0 \mathrm{~K}$ up to room temperatures. Good agreement was observed between theoretical and experimental heat capacities, which makes it possible to combine theoretical and experimental data to determine the standard entropies. Data for the liquid phase were described using a two state model. During the assessment, careful analysis of the experimental data was carried out. In order to fulfil the need for a precise evaluation of $S^{0}{ }_{298}$ we needed to use an additional technique using multiple Einstein functions, which allows the experimental heat capacity and enthalpy data for the solid phase to be approximated accurately from $0 \mathrm{~K}$ up to the melting point and to estimate solid phase transition entropy and enthalpy which are difficult to measure due to a high activation barrier. Additional measurements of heat capacity were carried out where existing data were scarce.
\end{abstract}

Key Words: tin, two state liquid model, expanded Einstein model, ab-initio calculation, adiabatic calorimetry

\title{
1. Introduction
}


The basis underlying the thermodynamic models used in the present work originates from the developments carried out at the Ringberg workshop in 1995 which were later published in the proceedings [1]. The models were then modified as a result of the SGTE collaboration. The aim of these models is to adopt a universal approach which incorporates multiple physical contributions to the thermodynamic properties [2] for the solid phases and uses a two state model to describe the thermodynamic properties of the liquid phase.

As was discussed earlier in our assessment of data for $\mathrm{Pb}[3]$, the decision to use the Einstein model rather than the Debye model was taken because of the complexities in the derivation of the thermodynamic functions such as the enthalpy, entropy and Gibbs energy using the Debye model. Furthermore, in practice, calculations are generally useful for temperatures only above $100 \mathrm{~K}$.

Additional parameters are introduced into the Einstein model in order to take into account anharmonicity, electronic effects and the correction from constant volume to constant pressure. There is also a requirement for an accurate re-evaluation of the value of $S_{298.15}^{\mathrm{o}}$, which requires a careful evaluation of the $C_{p}$ data from $0 \mathrm{~K}$ to the melting point. In order to do this we used a technique and software developed at MSU [4-5], which allows an detailed analysis of the experimental heat capacity and enthalpy data for the solid phase to be carried out and an accurate approximation from $0 \mathrm{~K}$ up to the melting point to be derived.

The extrapolation of data for the solid phase above the melting point was carried out in a similar way to previous work towards the definition of data for the elements in the SGTE database [6] by merging the heat capacity function of the solid phase to that of the liquid phase at high temperatures above the melting point.

The two state model for the liquid phase was developed by Ágren [7] and later accepted during the Ringberg workshop [8]. This approach has also been successfully applied in the recent work for other elements [9-12].

\section{Literature analysis}

Reviews

At ambient pressures $\mathrm{Sn}$ is stable in two crystalline forms in addition to the liquid phase. At temperatures below $286.35 \mathrm{~K} \mathrm{Sn}$ is stable in a diamond structure similar to Ge and $\mathrm{Si}$ [13] and is commonly referred to as grey tin. Above this temperature and up to the melting point, Sn is stable in a body centred tetragonal phase (white tin). The melting point $505.078 \mathrm{~K}$ [14] is fixed on the ITS-90 temperature scale. The transformation between grey tin and white tin is notoriously sluggish especially on cooling and this makes it possible to study the properties of white tin even down to $0 \mathrm{~K}$. 
The data for the grey tin have been reviewed by Hultgren [15] (Figure 1a). There are several reviews on the thermodynamic data for white tin. One of the earliest corresponds to Stull and Sinke [16]. Later two more reviews were carried out by Corruccini and Gniewek [17] and Kelley [18]. The first of these covered the experimental data from $0 \mathrm{~K}$ to $300 \mathrm{~K}$ and the latter from $350 \mathrm{~K}$ up to the melting point (Figure 1b,c). The recommended data from Kelley [18] overlap with those from Stull and Sinke [16]. The later review of Hultgren [15] covers the interval from $0 \mathrm{~K}$ to the melting point. It should be noted that the resulting data in the temperature interval where white tin is stable phase are lower than those obtained by Kelley [18], while the low temperature interval is in agreement with the review of Corruccini and Gniewek [17]. More recent reviews were carried out by Cox et al. [19] and Gurvich et al. [20], which are in a good agreement with the data from Hultgren [15] up to room temperature. At the high temperatures, especially close to the melting point, the data from Cox et al. [19] and Gurvich et al. [20] are higher than those recommended by Hultgren [15] but still lower than those from Kelley [18].

There are a large number of reviews of data for the liquid phase (Figure 1d). The earlier reviews suggested a constant $C_{p}$ for the liquid phase, while the more recent evaluations report the $C_{p}$ values decreasing immediately above the melting point and then either remaining constant [15] or increasing again [19-20]. It should be also noted that the more recent reviews suggest that the $C_{p}$ of the solid white tin is higher than that of the liquid phase in the region of the melting point.

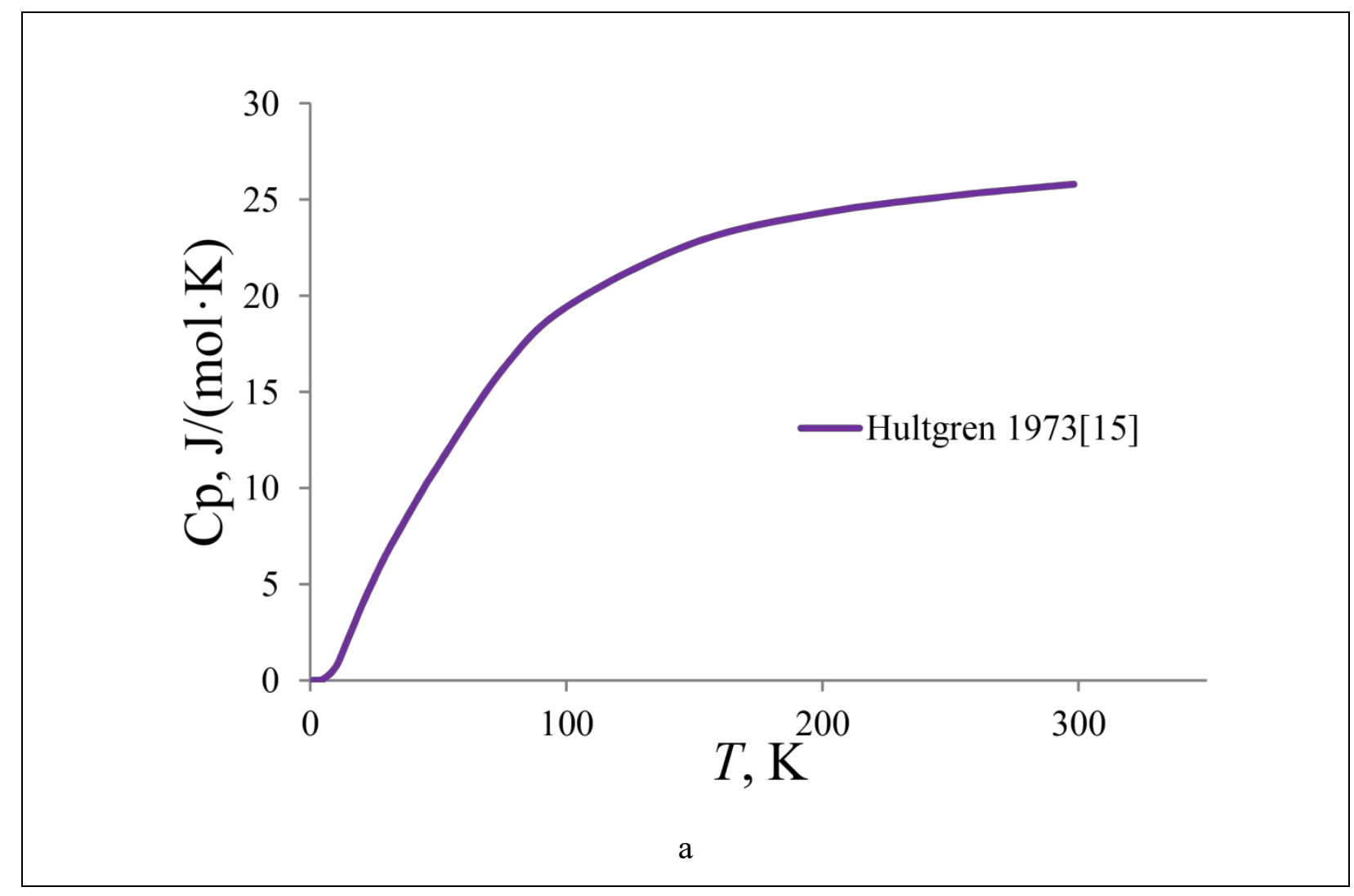




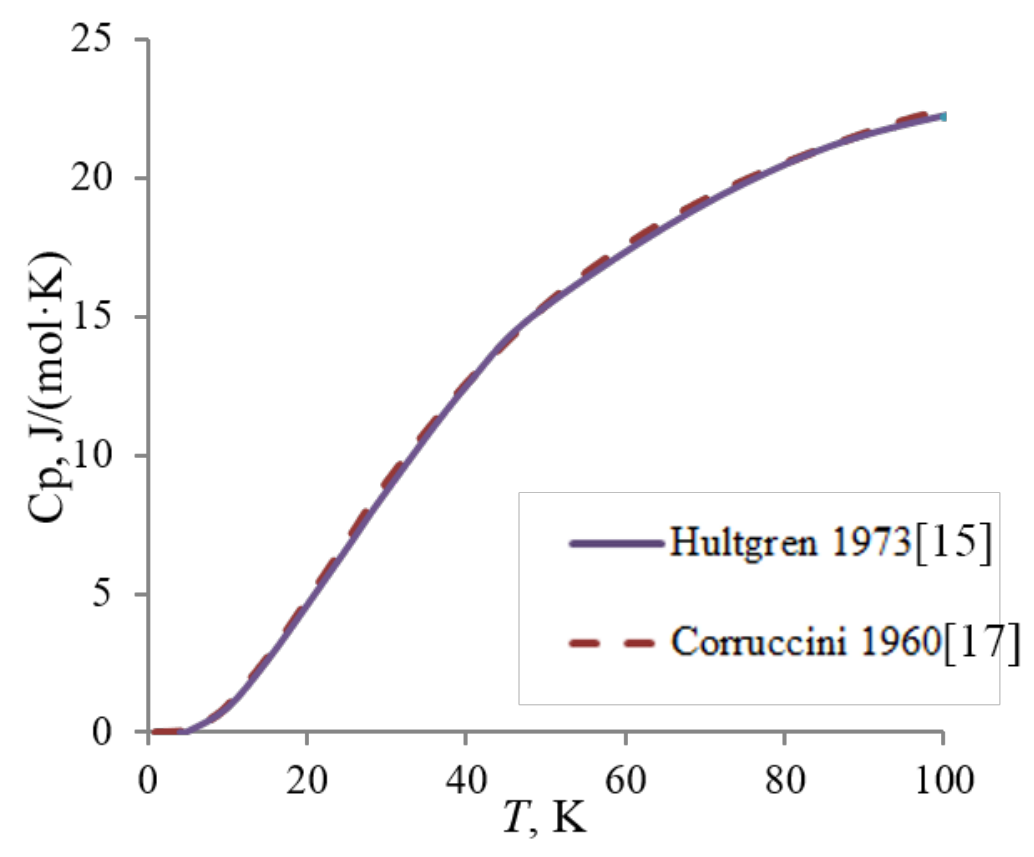

b

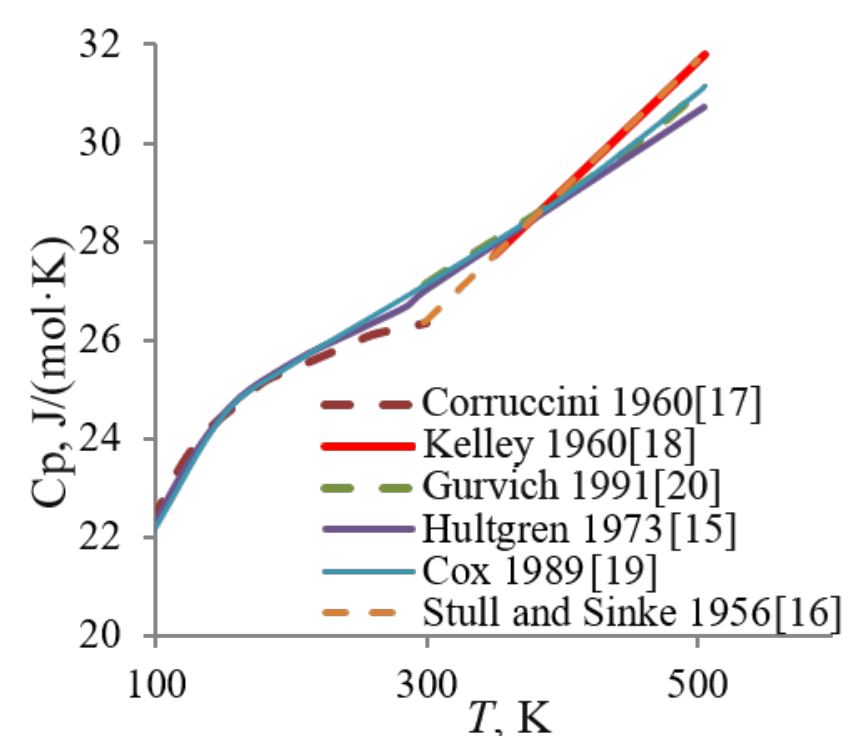

c

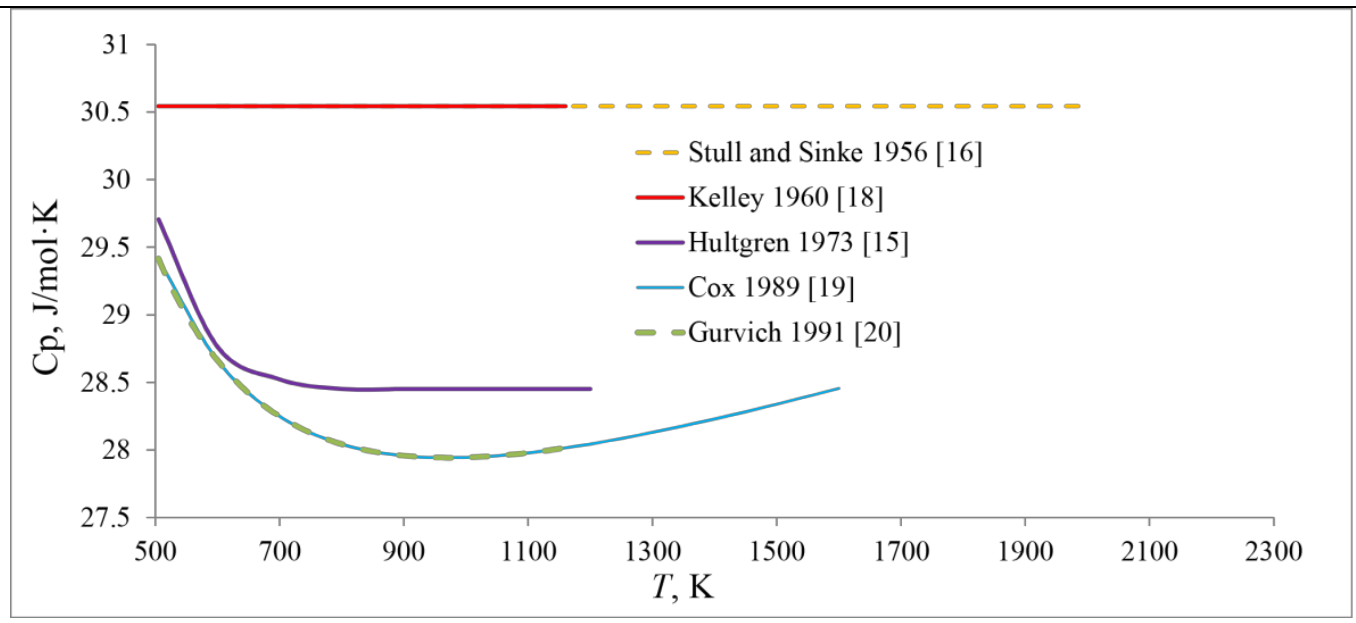


d

Figure 1 - Comparison of heat capacity calculated from assessed datasets: a) grey tin; b,c) white tin; d) Liquid tin. Please note that the curves are drawn from the values tabulated by the assessors and are therefore smooth.

\section{Heat capacity of $\alpha$-tin (Grey tin)}

The information about heat capacity measurements on solid tin are summarized on Figures 2 and 3 and Table 1.

The heat capacity of the grey tin was measured in the temperature range $79.8-288.9 \mathrm{~K}$ by Brönsted [21]. They are rather lower than the extrapolated values for room temperature obtained in later work. Rodebush [22] explained this by noting Brönsted [21] worked with finely divided metal in the container, which made it difficult to obtain thermal equilibrium at low temperatures. The later measurements of Lange [23] are higher than those of Brönsted [21] and were later confirmed by the results obtained by Hill [24] by adiabatic calorimetry. These data were given more weight in the present work in the temperature range 7-102 K. Lange [23] made an extrapolation of the data to the room temperature $(283.7 \mathrm{~K})$ giving a result for the heat capacity at $288 \mathrm{~K}$ of $25.65 \mathrm{~J} /(\mathrm{mol} \cdot \mathrm{K})$, which is appreciably higher than the value measured by Brönsted [21] of $24.73 \mathrm{~J} /(\mathrm{mol} \cdot \mathrm{K})$. Because these values were extrapolated in the temperature interval between 102 and $288 \mathrm{~K}$ more weight was given to the data from Brönsted [21] keeping in mind that it may be slightly too low. It should be noted that the data of Brönsted [21] suggest an almost constant behavior of the $C_{p}$ at high temperatures with a very slight increase. In contrast, in the review of Hultgren the heat capacity increases with the temperature.

The heat capacity over the low temperature interval was measured by Webb and Wilks in 1955 [25] and their data are in reasonable agreement with the data from Lange [23].

From the preceding discussion, it may be concluded that the measurement of the heat capacity of grey tin should be an object of special investigation. According to IUPAC recommendation, thermodynamic properties which have been obtained by only one scientific group should be seen as preliminary. As can be seen from Figure 2, the range of temperatures which overlap in the data in the scientific literature is too small $(75-100 \mathrm{~K})$. 


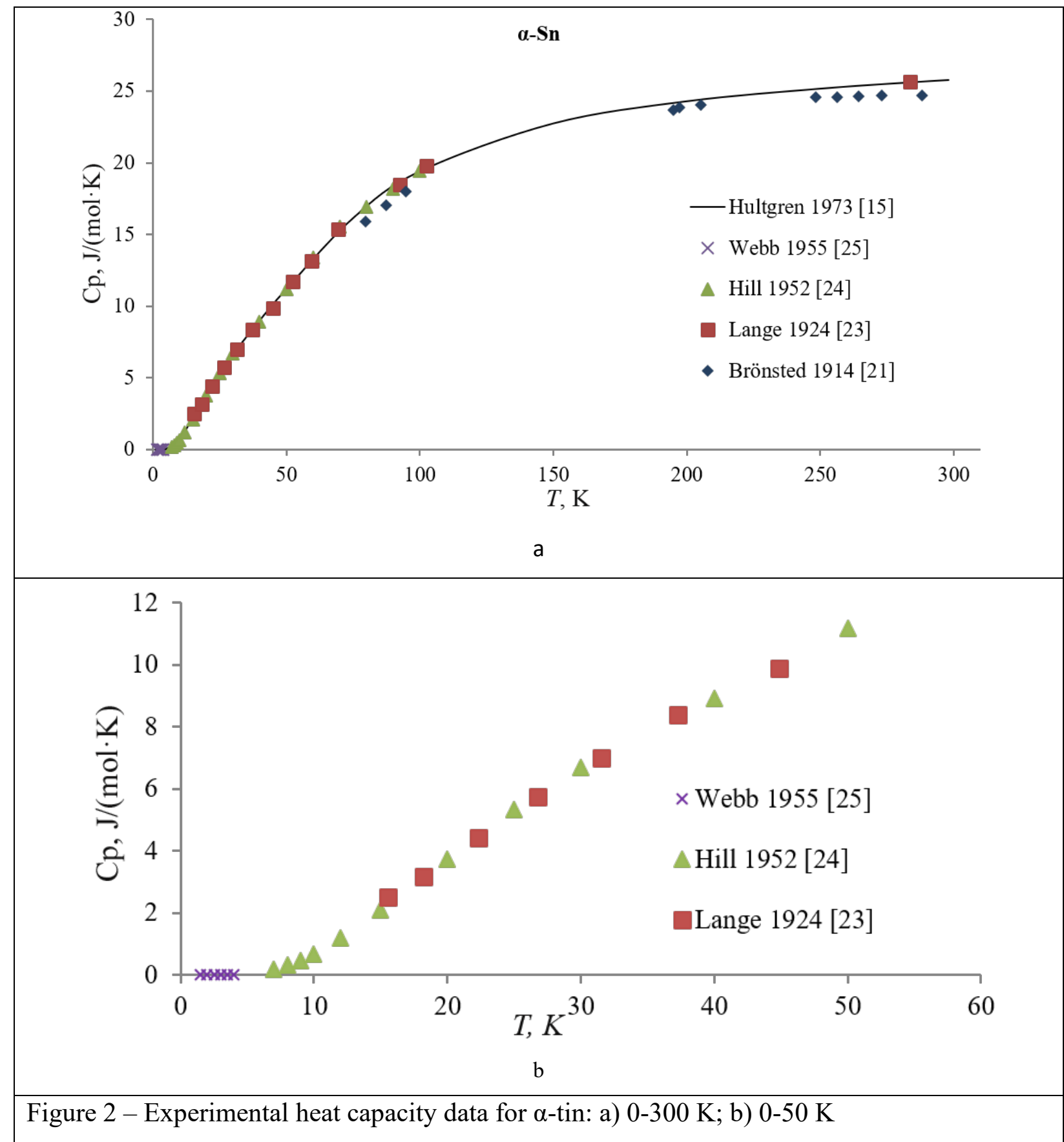

Heat capacity of $\beta$-tin (White tin)

The low temperature heat capacity of the white tin (Figures $3 \mathrm{a}-\mathrm{b}$ ) was measured by Keesom and van den Ende (2-20 K) [26], Lange (9.1-101.1 K) [23], Corak and Satterthwaite (1.122- 4.341 K) [27], Ramanathan and Satterthwaite (3.77-4.08 K) [28], Zavaritskii (3.16-4.33 K) [29], Bryant (0.4-4.389 K) [30], O’Neal (0.009-1.126 K) [31], Cetas (4-30 K) [32], Naumov et al. (3.97-311 K) [33], Keesom and Van Laar (1.067-3.768 K) [34] and Yaqub (0.604-1.653 K) [35]. The superconducting point was determined to be at $3.71 \mathrm{~K}$ by Keesom [26,34] and later confirmed by Ramanathan and Srinivasan [28]. It was observed that when no magnetic field is applied the discontinuity is detected at the normal transition point. Later Keesom and van Laar reported that 
their early measurements [26] were not accurate enough due to the insensitivity of the constantan (copper-nickel alloy based) thermometer [34]. In their later work [34] they carried out new investigations of the low temperature heat capacity in the normal state by applying a magnetic field of $23794 \mathrm{~A} / \mathrm{m}$ (299 gauss). The obtained values are lower than those in previous measurements and are in a good agreement with more recent work of Zavaritskii [29] and higher temperature values from Corak and Satterthwaite [27] and Ramanathan and Srinivasan [28]. No discontinuity was observed in this case (Figure 3a). Corak and Satterthwaite [27] applied the magnetic field of $63816 \mathrm{~A} / \mathrm{m}$ (800 oersted (oe)) in order obtain the data for the normal state, however the transition is still observed and the values are in agreement with early work of Keesom and van den Ende [26] where no magnetic field was applied. O’Neal [31] applied magnetic field of $79770 \mathrm{~A} / \mathrm{m}$ (1000 oe). The data from O'Neal [31] are higher than the earlier measurements of Keesom and van den Ende [26], Bryant [30] and Corak and Satterthwaite [27], but in agreement with Keesom and van Laar [34] and Yaqub [35]. The data from Bryant [30] are seriously lower than the results from the other work both at temperatures below and higher than $3.7 \mathrm{~K}$. These data were excluded from consideration in our work. Above the $3.7 \mathrm{~K}$ there is good agreement between the experimental data from Keesom and van den Ende [26], Corak and Satterthwaite [27], Lange [23], Zavaritskii [29], Cetas [32] and the most recent measurements from Naumov et al. [33] (Figure 3b).

In the temperature interval between 50 and $300 \mathrm{~K}$ (Figures $3 \mathrm{c}-\mathrm{d}$ ) there are experimental data from Brönsted [21], Lange [23], Rodebush [22], Cetas [32], Kramer and Nölting [36] and Naumov et al. [33] (Figure 3c). The early measurements from Brönsted [21] and Lange [23] have larger uncertainty. For this reason these data were given a lower weight. There is almost ideal agreement between the measurements from Rodebush [22], Cetas [32], Kramer and Nölting [36] and Naumov et al. [33].

The heat capacity in the higher temperature interval from $311 \mathrm{~K}$ up to the melting point was measured only by Klinghardt [37], Kramer and Nölting [36] and Bartenev [38] (Figure 3d). The data from Klinghardt are very scattered [37]. The results from Bartenev [38] are higher than the other results $[36,37]$.

Finishing a review of literature data about tin heat capacity, it can be concluded that white tin has been investigated more thoroughly than grey tin. In case of white tin, measurements of $C_{p}$ in the temperature interval 110-190 K only, are not available. For this reason it was decided to carry out an additional experimental investigation of the heat capacity of white tin in this temperature interval. 


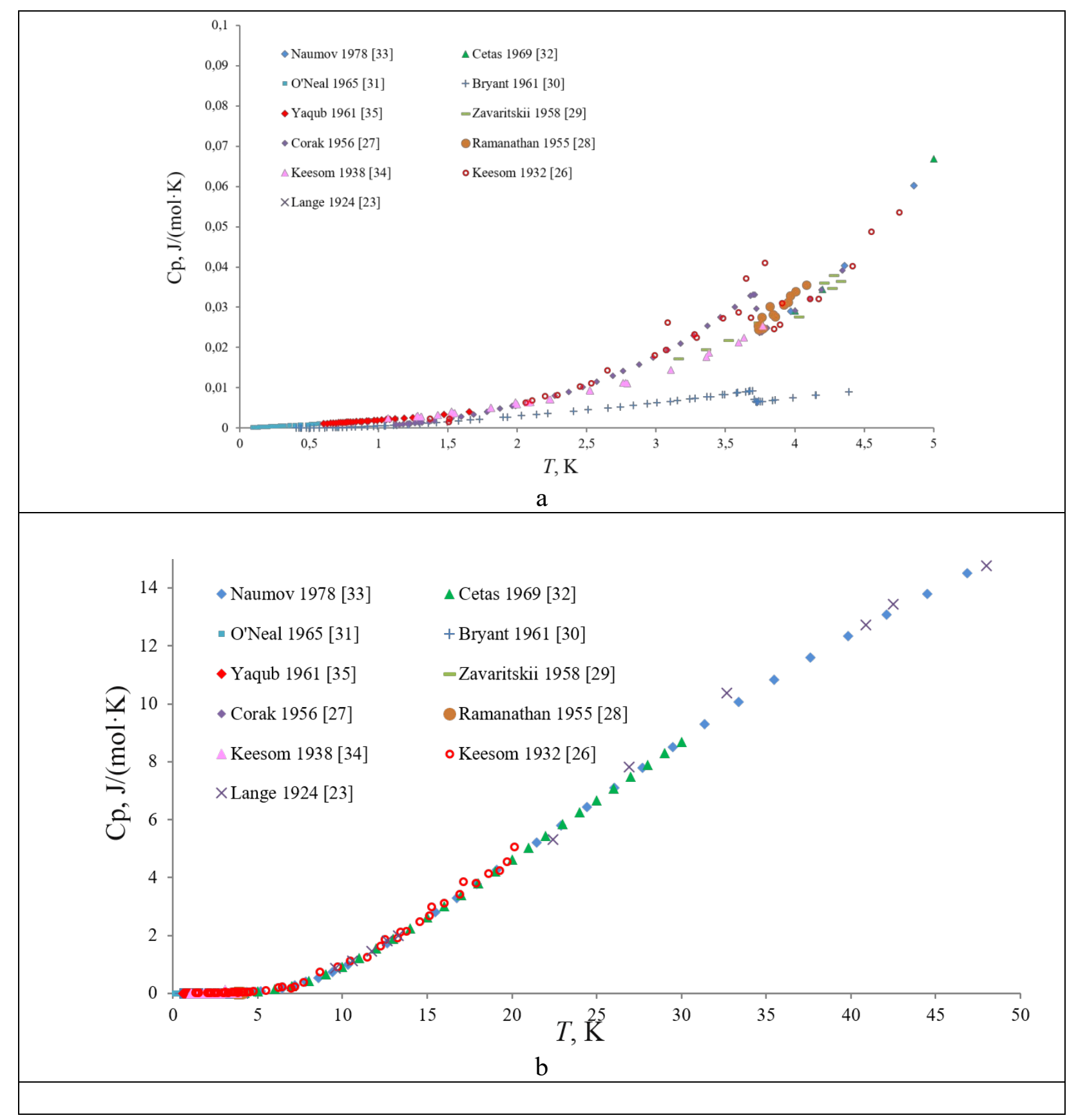




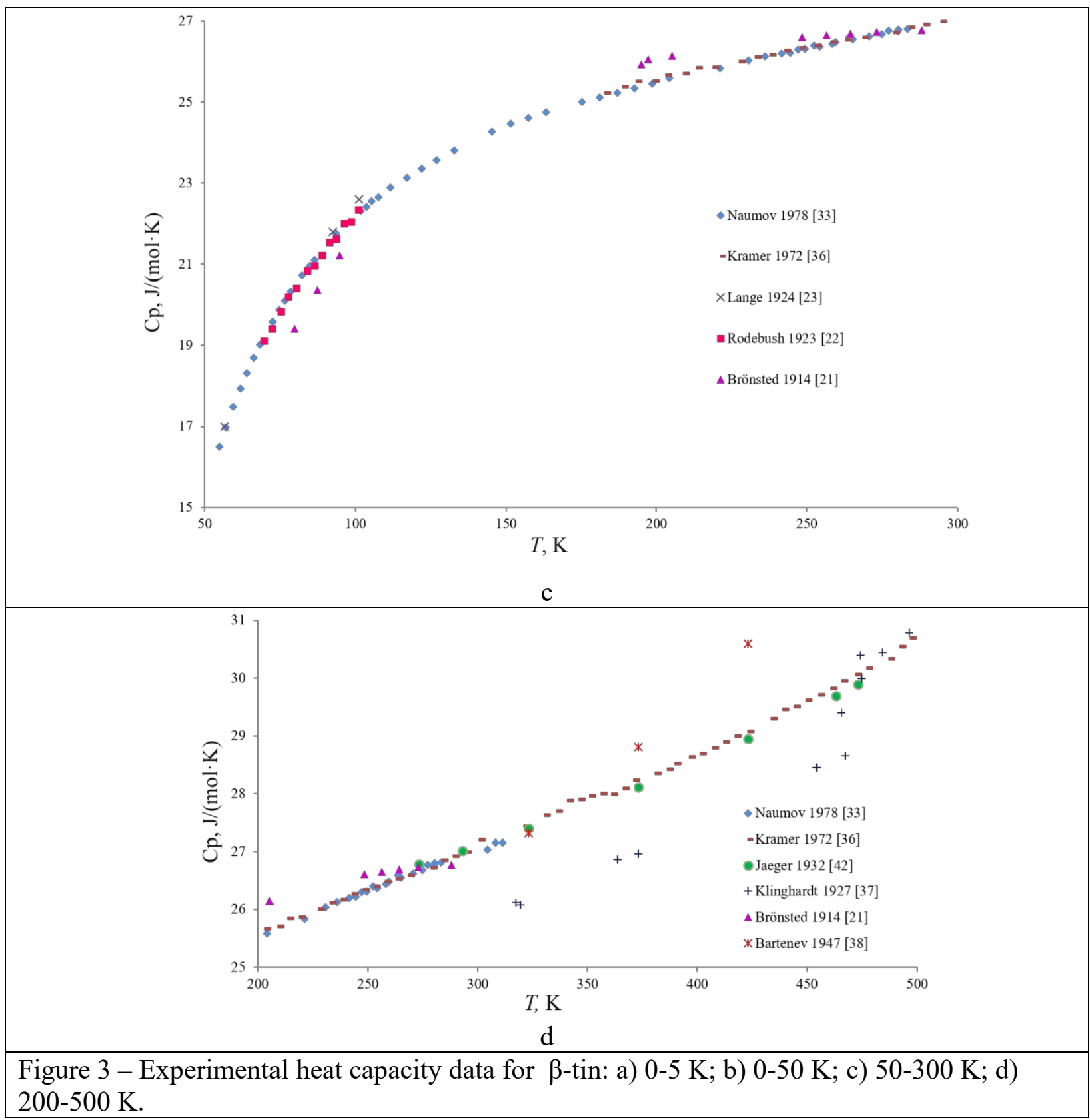

Table 1. Experimental determinations of the heat capacity

\begin{tabular}{|c|c|c|c|c|c|}
\hline $\begin{array}{c}\text { Temperature } \\
\text { interval, K }\end{array}$ & $\begin{array}{c}\text { Relative } \\
\text { uncertainty, \% }\end{array}$ & Method & $\begin{array}{l}\text { Purity as reported } \\
\text { in the original } \\
\text { publications, } \%\end{array}$ & Weight & Reference \\
\hline \multicolumn{6}{|c|}{$\alpha$-Tin (Grey tin) } \\
\hline $1.5-4$ & $1 \%$ & $\begin{array}{c}\text { Adiabatic } \\
\text { calorimetry }\end{array}$ & $\mathrm{n} / \mathrm{a}$ & $\begin{array}{l}1 \text { (due to the } \\
\text { absence of } \\
\text { other data) }\end{array}$ & $\begin{array}{l}\text { Webb and } \\
\text { Wilks [25] }\end{array}$ \\
\hline $7-100$ & $\begin{array}{c}1 \% \text { above } 10 \mathrm{~K}, \\
\text { below } 10 \mathrm{~K} \text { the } \\
\text { accuracy decreases } \\
\text { down to } 20 \%\end{array}$ & $\begin{array}{c}\text { Adiabatic } \\
\text { calorimetry }\end{array}$ & $99.95 \%$ & $\begin{array}{c}1 \text { in the } \\
\text { temperature } \\
\text { interval above } \\
10 \mathrm{~K}, 0.1 \text { below } \\
10 \mathrm{~K}\end{array}$ & $\begin{array}{c}\text { Hill and } \\
\text { Parkinson } \\
{[24]}\end{array}$ \\
\hline $15.5-102.6$ & $3 \%$ & $\begin{array}{c}\text { Adiabatic } \\
\text { calorimetry }\end{array}$ & $\mathrm{n} / \mathrm{a}$ & 1 & Lange [23] \\
\hline
\end{tabular}




\begin{tabular}{|c|c|c|c|c|c|}
\hline $79.8-288.1$ & $\begin{array}{c}1 \%, \\
\text { up to } 5 \% \text { lower } \\
\text { than data from } \\
\text { Lange [21] and } \\
\text { Hill and Parkinson } \\
{[22]}\end{array}$ & $\begin{array}{c}\text { Adiabatic } \\
\text { calorimetry }\end{array}$ & $\mathrm{n} / \mathrm{a}$ & $\begin{array}{c}0.1 \text { in the } \\
\text { temperature } \\
\text { interval } 79.8- \\
100 \mathrm{~K} ; 0.8 \text { in } \\
\text { the } \\
\text { temperature } \\
\text { interval 100- } \\
288.1 \text { (due to } \\
\text { the absence of } \\
\text { other data) }\end{array}$ & $\begin{array}{c}\text { Brönsted } \\
\text { [21] }\end{array}$ \\
\hline \multicolumn{6}{|c|}{$\beta$-Tin (White tin) } \\
\hline $\begin{array}{c}0.1-1 \\
\text { superconduc } \\
\text { tive state/ } \\
0.08-4.2 \mathrm{~K} \\
\text { normal state } \\
(79770 \mathrm{~A} / \mathrm{m} \\
(1000 \mathrm{O})) \\
\text { magnetic } \\
\text { field) }\end{array}$ & $1 \%$ & $\begin{array}{c}\text { Vacuum } \\
\text { adiabatic } \\
\text { calorimetry }\end{array}$ & $99.9999 \%$ & 1 & O’Neal [31] \\
\hline $\begin{array}{c}0.4374- \\
4.389 \mathrm{~K} \\
\text { superconduc } \\
\text { tive state/ } \\
0.4026- \\
3.874 \mathrm{~K} \\
\text { normal state } \\
(39885 \mathrm{~A} / \mathrm{m} \\
(500 \mathrm{Oe}) \\
\text { magnetic } \\
\text { field) }\end{array}$ & $1-3 \%$ & $\begin{array}{c}\text { Vacuum } \\
\text { adiabatic } \\
\text { calorimetry }\end{array}$ & $99.999 \%$ & 1 & Bryant [30] \\
\hline $\begin{array}{c}0.604- \\
1.653 \mathrm{~K} \\
\text { normal state } \\
(39789 \mathrm{~A} / \mathrm{m} \\
(500 \text { gauss }))\end{array}$ & $1-2 \%$ & $\begin{array}{c}\text { Adiabatic } \\
\text { calorimetry }\end{array}$ & $99.9 \%$ & 1 & Yaqub [35] \\
\hline $\begin{array}{c}1.13-3.982 \\
\text { superconduc } \\
\text { tive state/ } \\
1.122-4.341 \\
\text { normal state } \\
(63816 \mathrm{~A} / \mathrm{m} \\
(800 \mathrm{Oe}) \\
\text { magnetic } \\
\text { field) }\end{array}$ & $\begin{array}{l}0.6 \% \text { normal state } \\
0.9 \% \text { superconducti } \\
\text { ve state }\end{array}$ & $\begin{array}{c}\text { Adiabatic } \\
\text { calorimetry }\end{array}$ & $99.999 \%$ & 1 & $\begin{array}{c}\text { Corak and } \\
\text { Satterthwaite } \\
{[27]}\end{array}$ \\
\hline $\begin{array}{l}1.373- \\
20.170\end{array}$ & $\mathrm{n} / \mathrm{a}$ & $\begin{array}{c}\text { Vacuum } \\
\text { adiabatic } \\
\text { calorimetry }\end{array}$ & $\mathrm{n} / \mathrm{a}$ & 0.5 & $\begin{array}{c}\text { Keesom and } \\
\text { van den } \\
\text { Ende }[26] \\
\end{array}$ \\
\hline $\begin{array}{c}1.143- \\
3.794 \mathrm{~K}\end{array}$ & $\mathrm{n} / \mathrm{a}$ & $\begin{array}{c}\text { Vacuum } \\
\text { adiabatic } \\
\text { calorimetry }\end{array}$ & $99.992 \%$ & 1 & $\begin{array}{c}\text { Keesom and } \\
\text { van Laar } \\
{[34]}\end{array}$ \\
\hline
\end{tabular}




\begin{tabular}{|c|c|c|c|c|c|}
\hline $\begin{array}{l}\text { superconduc } \\
\text { tive state/ } \\
1.537-3.768 \\
\text { normal } \\
\text { state }(23794 \\
\text { A/m }(299 \\
\text { gauss })) \\
\end{array}$ & & & & & \\
\hline $\begin{array}{l}1.72-3.5 \\
\text { superconduc } \\
\text { tive state/ } \\
3.97-311.43 \\
\text { normal state }\end{array}$ & $\begin{array}{c}0.5 \% \text { for the } 1.7- \\
3.7 \mathrm{~K} ; 0.36 \% \text { for } \\
\text { the } 3.8-17 \mathrm{~K} \text {; } \\
0.03 \% \text { for the } 17 \text { - } \\
250 \mathrm{~K}, 0.08 \% \\
\text { above } 250 \mathrm{~K}\end{array}$ & $\begin{array}{l}\text { Adiabatic } \\
\text { calorimetry }\end{array}$ & $\begin{array}{c}\text { Monocrystalline } \\
\text { sample, } \\
99.9999 \%\end{array}$ & 1 & $\begin{array}{c}\text { Naumov et } \\
\text { al. [33] }\end{array}$ \\
\hline $3.16-4.33$ & $\mathrm{n} / \mathrm{a}$ & $\begin{array}{c}\text { Adiabatic } \\
\text { calorimetry }\end{array}$ & $99.998 \%$ & 1 & $\begin{array}{c}\text { Zavaritskii } \\
{[29]}\end{array}$ \\
\hline $\begin{array}{l}3.7675- \\
4.0835\end{array}$ & $3 \%$ & $\begin{array}{l}\text { Vacuum } \\
\text { adiabatic } \\
\text { calorimetry }\end{array}$ & $\mathrm{n} / \mathrm{a}$ & 1 & $\begin{array}{c}\text { Ramanathan } \\
\text { and } \\
\text { Srinivasan } \\
\text { [28] } \\
\end{array}$ \\
\hline $4-30$ & $0.5 \%$ & $\begin{array}{l}\text { Tray calorimeter } \\
\text { using heat-pulse } \\
\text { method }\end{array}$ & 99.999 & $\begin{array}{c}0 \\
\text { (no raw data } \\
\text { only smoothed } \\
\text { values) } \\
\end{array}$ & Cetas [32] \\
\hline $15.5-102.6$ & $3 \%$ & $\begin{array}{c}\text { Adiabatic } \\
\text { calorimetry }\end{array}$ & $\mathrm{n} / \mathrm{a}$ & 0.8 & Lange [23] \\
\hline $69.63-101$ & $1 \%$ & $\begin{array}{l}\text { Adiabatic } \\
\text { calorimetry }\end{array}$ & $\mathrm{n} / \mathrm{a}$ & 0.8 & $\begin{array}{l}\text { Rodebush } \\
\text { [22] }\end{array}$ \\
\hline $79.8-288.1$ & $\begin{array}{c}1 \%(\text { as published }) \\
\text { Up to } 5 \% \text { lower } \\
\text { than data from } \\
\text { Lange[21] and } \\
\text { Hill[22] }\end{array}$ & $\begin{array}{l}\text { Adiabatic } \\
\text { calorimetry }\end{array}$ & $\mathrm{n} / \mathrm{a}$ & $\begin{array}{c}0.1 \text { in the } \\
\text { temperature } \\
\text { interval } 79.8- \\
100 \mathrm{~K}\end{array}$ & $\begin{array}{l}\text { Brönsted } \\
{[21]}\end{array}$ \\
\hline $\begin{array}{c}182.875- \\
505.76 \\
\end{array}$ & $1 \%$ & $\begin{array}{c}\text { Adiabatic } \\
\text { calorimetry }\end{array}$ & $99.999 \%$ & 1 & $\begin{array}{l}\text { Kramer and } \\
\text { Nölting [36] }\end{array}$ \\
\hline $\begin{array}{l}317.51- \\
518.45\end{array}$ & $1 \%$ & $\begin{array}{c}\text { Method of } \\
\text { heating with } \\
\text { glowing electrons }\end{array}$ & $\mathrm{n} / \mathrm{a}$ & 0 & $\begin{array}{c}\text { Klinghardt } \\
\text { [37] }\end{array}$ \\
\hline $\begin{array}{l}323.15- \\
473.15\end{array}$ & $1 \%$ & $\begin{array}{l}\text { Heating/cooling } \\
\text { method }\end{array}$ & $\begin{array}{c}99.84 \% \\
(0.1 \% \mathrm{Cu}+0.06 \\
\text { other impurities })\end{array}$ & 0 & $\begin{array}{l}\text { Bartenev } \\
{[38]}\end{array}$ \\
\hline \multicolumn{6}{|c|}{ Liquid } \\
\hline $480-620$ & $2 \%$ & DSC & $99.999 \%$ & 1 & $\begin{array}{c}\text { Chen and } \\
\text { Turnbull } \\
{[50]}\end{array}$ \\
\hline $506.2-804.1$ & $5 \%$ & & $99.99 \%$ & 1 & Heffan [48] \\
\hline $\begin{array}{l}523.15- \\
623.15\end{array}$ & $1 \%$ & $\begin{array}{l}\text { Heating/cooling } \\
\text { method }\end{array}$ & $\begin{array}{c}99.84 \% \\
(0.1 \% \mathrm{Cu}+0.06 \\
\text { other impurities }) \\
\end{array}$ & 0 & $\begin{array}{l}\text { Bartenev } \\
\text { [38] }\end{array}$ \\
\hline
\end{tabular}




\begin{tabular}{|c|c|c|c|c|c|}
\hline $531-834.5$ & $1 \%$ & $\begin{array}{c}\text { Method of } \\
\text { heating with } \\
\text { glowing electrons }\end{array}$ & n/a & 0 & $\begin{array}{c}\text { Klinghardt } \\
{[37]}\end{array}$ \\
\hline $867-1227.6$ & $2.4 \%$ & $\begin{array}{c}\text { Method of radial } \\
\text { temperature } \\
\text { waves }\end{array}$ & $\mathrm{n} / \mathrm{a}$ & 0 & $\begin{array}{c}\text { Yurchak and } \\
\text { Philippov } \\
{[49]}\end{array}$ \\
\hline
\end{tabular}

\section{Enthalpy increments measurements of solid tin}

A large fraction of the enthalpy increment measurements and latent heat measurements, especially very early ones, were made using water or ice calorimeters. In the very early studies, the actual measurements were frequently concerned with the change in temperature of the water rather than determination of the heat as we may understand it now. These early experiments actually depended critically on the definition of the calorie as the heat needed to increase the temperature of $1 \mathrm{~g}$ of water by 1 degree. However the temperatures of the water at which the measurements were carried out were different [39] and the heat needed to raise the temperature from 0 to $1^{0} \mathrm{C}$ and from 15 to $16{ }^{\circ} \mathrm{C}$ are different. Different calories were used even after 1935 when thermochemical calorie was determined to be $4.184 \mathrm{~J}$, and even after the international calorie was accepted to be $4.1868 \mathrm{~J}$ in 1956 [40]. The $15 \mathrm{C}$ calorie was frequently used in experimental measurements. The value was determined as the amount of energy required to warm 1 gram of water from 14.5 to $15.5 \mathrm{C}$ and was accepted to be equal to $4.1855 \mathrm{~J}$. The $20 \mathrm{C}$ calorie was mostly used in the works of USSR scientists in 1934-1957. It was determined as energy needed to warm 1 gram of water from 19.5 to $20.5 \mathrm{C}$ and was equal to $4.182 \mathrm{~J}$. This gives an additional, although small, deviation of several Joules when we interpret the original values. One should also keep in mind that the temperatures of the calorimeter were different. For example in the earliest measurements of Wüst et al. [41] the actual measurement was for $H^{\circ}(T)-H^{\circ}(273)$. Similar measurements were carried out later by Jaeger and Bottema [42], Figure 4a, and they provide more reliable data, although both set of measurements are in reasonable agreement. Iitaka [43], Awbery and Griffiths [44] and Umino [45] carried out measurements of $H^{\circ}(T)-H^{\circ}(293)$. From this set of measurements the data from Awbery and Griffiths [44] and Umino [45] are in a good agreement with each other, while data from Iitaka differ significantly [43], Figure 4b. The most recent measurements were carried by Genot [46], however the actual temperature of the calorimeter was specified in the paper as $471 \mathrm{~K}\left(198{ }^{0} \mathrm{C}\right)$, which makes it impossible to compare with experimental measurements from other authors.

Table 2 - experimental values of the enthalpy increments for solid white tin

\begin{tabular}{|c|c|c|c|c|c|c|}
\hline $\begin{array}{c}\text { Temperature } \\
\text { interval, } \mathrm{K}\end{array}$ & $\begin{array}{c}\text { Relative } \\
\text { uncertaint } \\
y, \%\end{array}$ & Method & $\begin{array}{c}\text { Purity as } \\
\text { reported in } \\
\text { the original }\end{array}$ & $\begin{array}{c}\text { Units to } \\
\text { be used } \\
\text { for }\end{array}$ & $\begin{array}{c}\text { Measured value } \\
\text { nefere } \\
\text { nce }\end{array}$ \\
\hline
\end{tabular}




\begin{tabular}{|c|c|c|c|c|c|c|}
\hline & & & $\begin{array}{c}\text { publications } \\
\%\end{array}$ & $\begin{array}{l}\text { transfer } \\
\text { into } \mathrm{J}\end{array}$ & & \\
\hline $\begin{array}{l}373.15- \\
493.15\end{array}$ & $5 \%$ & $\begin{array}{l}\text { Oberhoffer } \\
\text { vacuum } \\
\text { calorimeter, } \\
\text { which is } \\
\text { Bunsen } \\
\text { calorimeter } \\
\text { combined } \\
\text { with electric } \\
\text { vacuum } \\
\text { furnace }\end{array}$ & $\mathrm{n} / \mathrm{a}$ & $\begin{array}{l}15^{\circ} \mathrm{C} \\
\text { calorie }\end{array}$ & $H^{\mathrm{o}}(T)-H^{\mathrm{o}}(273)$ & $\begin{array}{l}\text { Wüst } \\
\text { et al. } \\
1918 \\
{[41]}\end{array}$ \\
\hline $357-474$ & $\mathrm{n} / \mathrm{a}$ & $\begin{array}{l}\text { Drop water } \\
\text { calorimeter } \\
\mathrm{Tc}=293.15\end{array}$ & $\begin{array}{c}99.79 \% \\
\text { purity } \\
0.084 \% \mathrm{~Pb} \\
0.054 \% \mathrm{Cu}, \\
0.035 \% \mathrm{Fe} \\
0.021 \mathrm{Zn}, \\
0.019 \% \mathrm{As}\end{array}$ & $\begin{array}{l}15^{\circ} \mathrm{C} \\
\text { calorie }\end{array}$ & $H^{\mathrm{o}}(T)-H^{\mathrm{o}}(293)$ & $\begin{array}{c}\text { Iitaka } \\
1919 \\
{[43]}\end{array}$ \\
\hline $\begin{array}{c}291.15- \\
560.15\end{array}$ & $\mathrm{n} / \mathrm{a}$ & $\begin{array}{l}\text { Drop water } \\
\text { calorimeter } \\
\text { Tc }=291.15\end{array}$ & $99.98 \%$ & $\begin{array}{l}20^{\circ} \mathrm{C} \\
\text { calorie }\end{array}$ & $H^{\circ}(T)-H^{\circ}(293)$ & $\begin{array}{c}\text { Awber } \\
\text { y and } \\
\text { Griffit } \\
\text { hs } \\
1926 \\
{[44]}\end{array}$ \\
\hline $323-873$ & $1 \%$ & $\begin{array}{l}\text { Drop water } \\
\text { calorimeter }\end{array}$ & $\begin{array}{c}99.989 \% \\
\text { purity with } \\
0.003 \% \mathrm{~Pb} \\
\text { and } 0.008 \% \\
\mathrm{Cu}\end{array}$ & $\begin{array}{l}15^{\circ} \mathrm{C} \\
\text { calorie }\end{array}$ & $H^{\mathrm{o}}(T)-H^{\mathrm{o}}(293)$ & $\begin{array}{c}\text { Umino } \\
1926 \\
{[45]}\end{array}$ \\
\hline $\begin{array}{c}273.15- \\
473.15\end{array}$ & $0.2 \%$ & $\begin{array}{c}\text { Drop } \\
\text { calorimetry }\end{array}$ & $\mathrm{n} / \mathrm{a}$ & $\begin{array}{c}\text { Not } \\
\text { obvious } \\
\text { taken as } \\
\text { thermoch } \\
\text { emical } \\
\text { calorie }\end{array}$ & $H^{\mathrm{o}}(T)-H^{\mathrm{o}}(293)$ & $\begin{array}{c}\text { Jaeger } \\
\text { and } \\
\text { Bottem } \\
\text { a } 1932 \\
{[42]}\end{array}$ \\
\hline $471-723$ & $1 \%$ & $\begin{array}{l}\text { Drop water } \\
\text { calorimeter }\end{array}$ & $\mathrm{n} / \mathrm{a}$ & $\begin{array}{l}\text { Thermoc } \\
\text { hemical } \\
\text { calorie }\end{array}$ & $H^{\circ}(T)-H^{\circ}(471)$ & $\begin{array}{c}\text { Genot } \\
1960 \\
{[46]}\end{array}$ \\
\hline
\end{tabular}




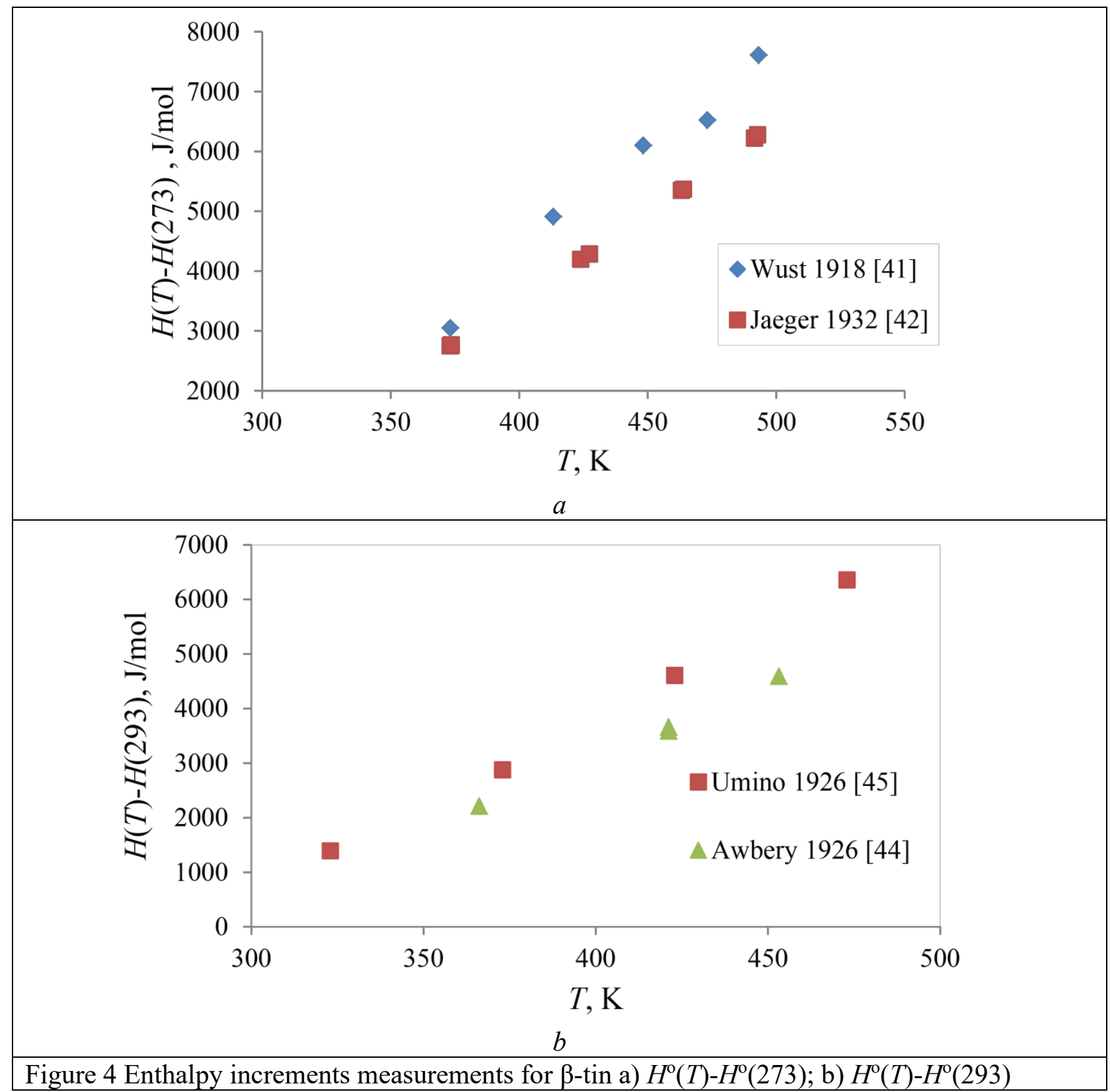

Enthalpy of $\alpha \rightarrow \beta$ transition

There is a lack of data for the enthalpy of $\alpha S n \rightarrow \beta S n$ transformation. Cohen and van Eijk [47] determined the heat of transformation as $3.05 \mathrm{~kJ} / \mathrm{mol}$ using an electrochemical cell consisting of the grey and white tin connected by an aqueous tin hexachloride solution. However, in more recent calorimetric work of Brönstedt [21], the enthalpy of transformation was determined to be $2.23 \mathrm{~kJ} / \mathrm{mol}$. Hultgren [15] estimated the heat of transformation to be $1.97 \mathrm{~kJ} / \mathrm{mol}$ and temperature of transformation as $286.35 \mathrm{~K}$ from a third law analysis. Even today the accuracy of the values both for enthalpy of transformation and the temperature of transformation are not well determined.

Heat capacity of Liquid tin. 
Heat capacity measurements of liquid tin have been carried out by Klinghardt [37], Bartenev [38], Heffan [48], Yurchak and Philippov [49] and Chen and Turnbull [50] (Figure 5, Table 1). Klighardt [37] carried out measurements from the melting point up to $835 \mathrm{~K}$, Yurchak and Philippov [49] carried out measurements using a radial temperature waves method from $867 \mathrm{~K}$ to $1227 \mathrm{~K}$. Both authors suggest an almost constant behavior of the heat capacity. The data from Yurchak and Philippov [49] suggest a slow increase in the heat capacity from $1100 \mathrm{~K}$. In contrast to these results, the measurements of Chen and Turnbull [50], Heffan [48] and Bartenev [38] suggest a decrease of the heat capacity in the temperature interval from the melting point to $804 \mathrm{~K}$. The results from these three studies are in a good agreement with each other (Figure 5).

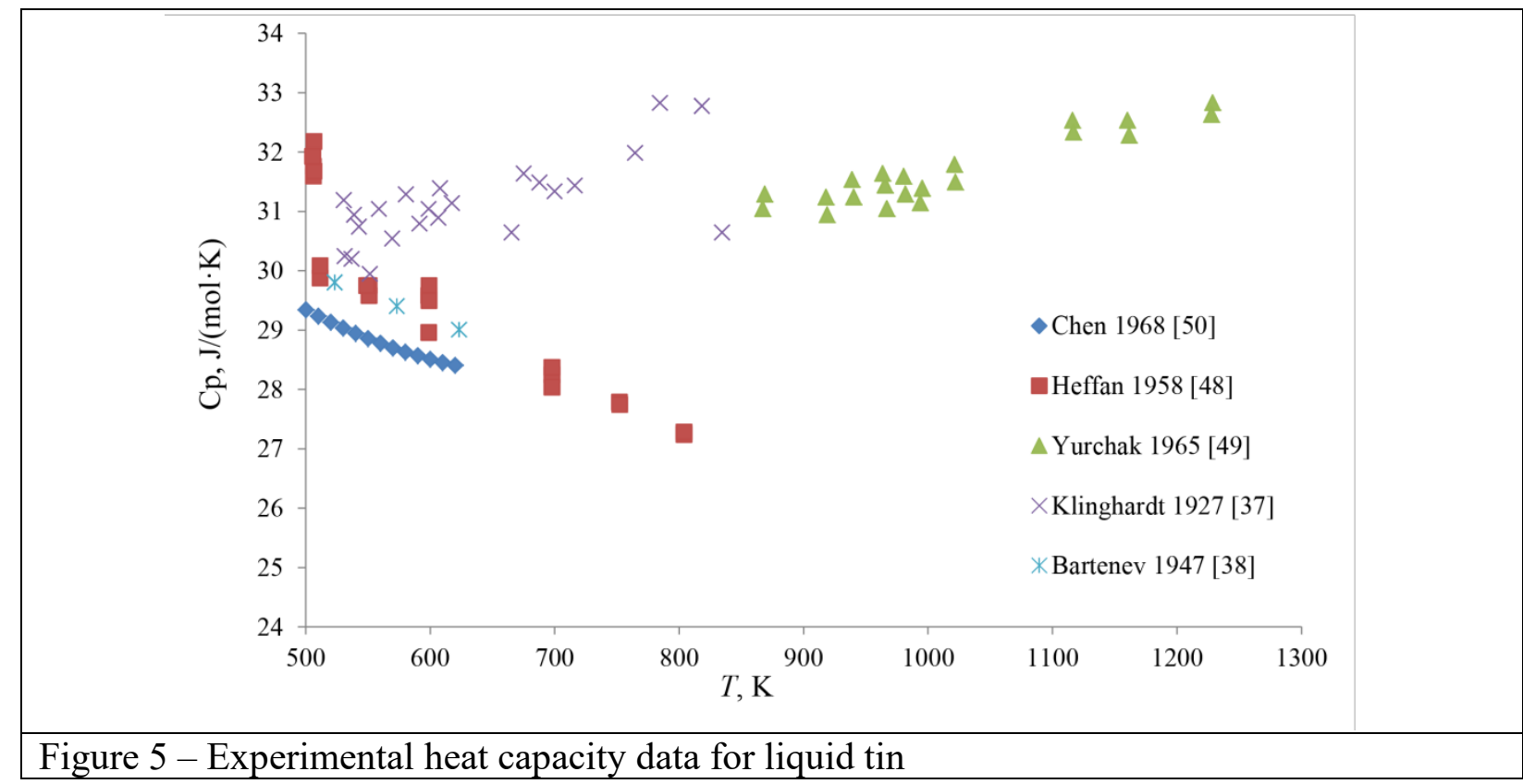

\section{Enthalpy increments measurements of the liquid tin}

The other source of thermodynamic data for liquid tin is from enthalpy drop measurements. Similar peculiarities were taken into account as in the analysis of data as for solid tin enthalpy drop data. A comparison of the data from Iitaka [43], Awbery and Griffiths [44] and Umino [45] showed that these results are in reasonable agreement (Figure 6). The only high temperature measurements were carried out by Feber et al. [51] These results seem to be in agreement with lower temperature data.

Table 3 - experimental values of the enthalpy increments for liquid tin

\begin{tabular}{|c|c|l|c|c|l|l|}
\hline $\begin{array}{c}\text { Tempera } \\
\text { ture } \\
\text { interval, } \\
\mathrm{K}\end{array}$ & $\begin{array}{c}\text { Relative } \\
\text { uncertaint } \\
\mathrm{y}, \%\end{array}$ & Method & $\begin{array}{c}\text { Purity as } \\
\text { reported in } \\
\text { the original } \\
\text { publications, } \\
\%\end{array}$ & $\begin{array}{c}\text { Units to be } \\
\text { used for } \\
\text { transfer } \\
\text { into J }\end{array}$ & Measured value & \\
\hline
\end{tabular}




\begin{tabular}{|c|c|c|c|c|c|c|}
\hline $\begin{array}{l}513.15- \\
1273.15\end{array}$ & $5 \%$ & $\begin{array}{l}\text { Oberhoffer vacuum } \\
\text { calorimeter, which } \\
\text { is Bunsen } \\
\text { calorimeter } \\
\text { combined with } \\
\text { electric vacuum } \\
\text { furnace }\end{array}$ & $\mathrm{n} / \mathrm{a}$ & $\begin{array}{l}15^{\circ} \mathrm{C} \\
\text { calorie }\end{array}$ & $H^{\mathrm{o}}(T)-H^{\mathrm{o}}(273)$ & $\begin{array}{l}\text { Wüst et al. } \\
1918 \text { [41] }\end{array}$ \\
\hline $536-785$ & & $\begin{array}{l}\text { Drop water } \\
\text { calorimeter } \\
\text { Tc=293.15 }\end{array}$ & $\begin{array}{c}99.79 \% \text { purity } \\
0.084 \% \mathrm{~Pb} \\
0.054 \% \mathrm{Cu}, \\
0.035 \% \mathrm{Fe} \\
0.021 \mathrm{Zn}, \\
0.019 \% \mathrm{As}\end{array}$ & $\begin{array}{l}15^{\circ} \mathrm{C} \\
\text { calorie }\end{array}$ & $H^{\circ}(T)-H^{\circ}(293)$ & $\begin{array}{c}\text { Iitaka } 1919 \\
{[43]}\end{array}$ \\
\hline $\begin{array}{c}506.15- \\
560.15\end{array}$ & $\mathrm{n} / \mathrm{a}$ & $\begin{array}{l}\text { Drop water } \\
\text { calorimeter } \\
\mathrm{Tc}=291.15 \\
\end{array}$ & $99.98 \%$ & $\begin{array}{l}20^{\circ} \mathrm{C} \\
\text { calorie }\end{array}$ & $H^{\mathrm{o}}(T)-H^{\mathrm{o}}(293)$ & $\begin{array}{c}\text { Awbery and } \\
\text { Griffiths } 1926 \\
{[44]}\end{array}$ \\
\hline $523-873$ & & $\begin{array}{l}\text { Drop water } \\
\text { calorimeter }\end{array}$ & $\begin{array}{c}99.989 \% \\
\text { purity with } \\
0.003 \% \mathrm{~Pb} \\
\text { and } 0.008 \% \\
\mathrm{Cu}\end{array}$ & $\begin{array}{l}15^{\circ} \mathrm{C} \\
\text { calorie }\end{array}$ & $H^{\mathrm{o}}(T)-H^{\mathrm{o}}(293)$ & $\begin{array}{c}\text { Umino } 1926 \\
{[45]}\end{array}$ \\
\hline $471-723$ & $1 \%$ & $\begin{array}{l}\text { Drop water } \\
\text { calorimeter }\end{array}$ & $\mathrm{n} / \mathrm{a}$ & $\begin{array}{c}\text { Thermoch } \\
\text { emical } \\
\text { calorie } \\
\end{array}$ & $\begin{array}{c}\text { Temperature of } \\
\text { calorimeter is } \\
\text { not known }\end{array}$ & $\begin{array}{c}\text { Genot } 1960 \\
{[46]}\end{array}$ \\
\hline $\begin{array}{l}1222- \\
1745\end{array}$ & $\pm 120 \mathrm{~J} / \mathrm{mol}$ & $\begin{array}{c}\text { An adiabatically } \\
\text { shielded drop } \\
\text { calorimeter } \\
\text { Tc }=298.15\end{array}$ & $99.9999 \%$ & $\begin{array}{l}\text { Thermoch } \\
\text { emical } \\
\text { calorie }\end{array}$ & $H^{\mathrm{o}}(T)-H^{\mathrm{o}}(298)$ & $\begin{array}{c}\text { Feber et al. } \\
1969 \text { [51] }\end{array}$ \\
\hline
\end{tabular}

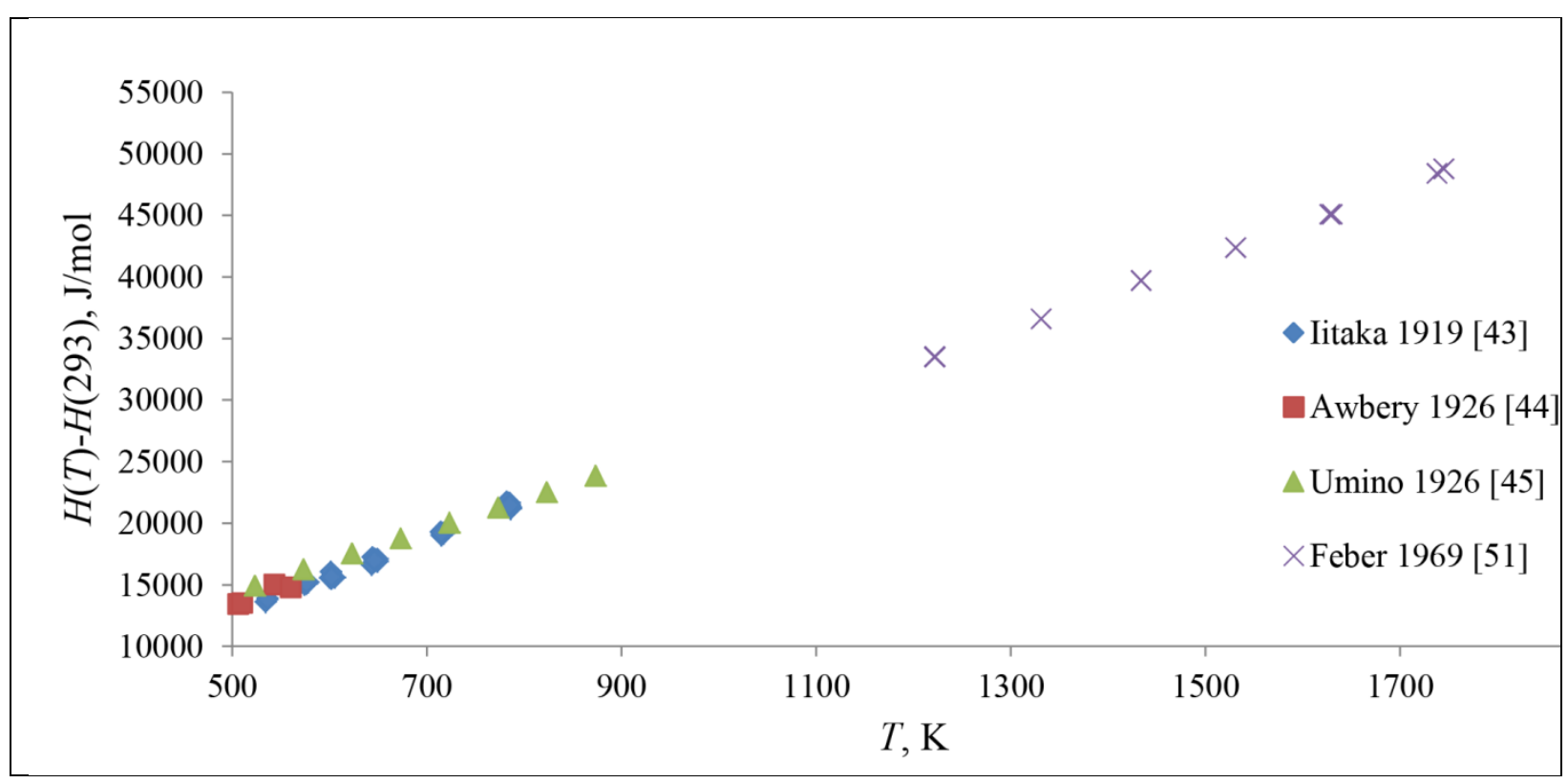


Figure 6 - Enthalpy increments measurements for liquid tin $H^{\mathrm{o}}(T)-H^{\mathrm{o}}(293)$ (Data from Feber et al. [51] are for $H^{\mathrm{o}}(T)-H^{\mathrm{o}}(298)$

\section{Fusion}

The melting temperature of tin is a fixed point of the ITS-90 and is defined to be $505.078 \mathrm{~K}$ [14]. This value is accepted in the present work. The earliest attempts to measure the enthalpy and temperature of fusion was made by Irvine and Black approximately in 1780 and were later cited and reproduced by Irvine Junior in 1804 [52]. This works refer to the time when the actual measurement was done relative to the temperature change of the water where the sample was placed. The work [52] provides detailed information for the investigations of the measurements for $\mathrm{Bi}$, but almost no details for the investigations on $\mathrm{Sn}$. For this reason the recalculated value from Stølen and Grønvold of $9110 \mathrm{~J} / \mathrm{mol}$ [40] seems to be rather speculative. There also could be a misunderstanding concerning the original units as the original investigation temperature was measured in Fahrenheit and the weight of samples in grains not calories per grams as indicated in [40].

Richards determined the value for the latent heat using a method and apparatus [39] similar to the one used by Pionchon [53], with the difference that sample was introduced from the temperature close to the melting point [54]. Despite the fact that for the early measurements the purity of the samples and sensitiveness of the equipment was not as good as in the later measurements still the obtained values for enthalpies of fusion are within experimental range of values we have for the more recent papers.

The analysis of data obtained from 1947 shows that the lowest values were obtained by Bartnev [55], Olsen [56] and Chiotti et al. [57]. It should be noted that in 1955 Olsen published 3 papers $[56,58-59]$ where the measurement of enthalpy of fusion of tin was carried out. The average value between 3 sets of measurements is $7046 \pm 170(\mathrm{~J} / \mathrm{mol})$. The highest values were obtained by Nagasaki and Fujita [60], Pascard [61] and Reznitskiy et al. [62]. The lowest and highest values were excluded from further analysis. In 1993 Grønvold [63] carried out additional investigations and updated the value for enthalpy of fusion of indium which had been used as a reference material for calibration of instruments (e.g. in the works of Alpaut and Heumann [64], Breuer and Eysel [65], Höhne et al. [66]). The average value between the remaining measurements is $7169 \mathrm{~J} / \mathrm{mol}$ with a deviation within $2 \%$ and is very close to the value $7179 \mathrm{~J} / \mathrm{mol}$ reported by Grønvold. Among the most recent measurements the most accurate seems to be the one reported by Grønvold, which was actually focused on determination of the enthalpy of fusion values, while for the other two, Wolf et al. [67] and Zahra and Zahra [68] were actually aiming to evaluate the precision of their 
instruments using the data from Grønvold as a reference point for comparison. Zahra and Zahra [68] also reported some instability of the baseline and several other shortcomings of the instrument which they used, which decreased the precision of their measurements in comparison with other works.

Table 4 - Experimental measurements of the enthalpies of fusion

\begin{tabular}{|c|c|c|c|c|c|c|}
\hline $\mathrm{T}, \mathrm{K}$ & $\begin{array}{c}H \text { fusion } \\
\mathrm{J} / \mathrm{mol}\end{array}$ & $\begin{array}{c}\text { Relative } \\
\text { uncertainty, } \\
\%\end{array}$ & Method & $\begin{array}{l}\text { Purity as } \\
\text { reported in the } \\
\text { original } \\
\text { publications, } \\
\%\end{array}$ & $\begin{array}{l}\text { Units to be } \\
\text { used for } \\
\text { transfer into J }\end{array}$ & $\begin{array}{c}\text { Reference/ } \\
\text { date }\end{array}$ \\
\hline \multirow[t]{2}{*}{501} & & & $\begin{array}{c}\text { Temperature } \\
\text { change } \\
\text { measurement of the } \\
\text { water in the water } \\
\text { calorimeter. }\end{array}$ & & & $\begin{array}{c}\text { Irvine [52] } \\
1804\end{array}$ \\
\hline & 6617.258 & $\begin{array}{c}3 \% \\
( \pm 99 \mathrm{~J} / \mathrm{mol})\end{array}$ & $\begin{array}{c}\text { Early thermal } \\
\text { analysis } \\
\text { measurement using } \\
\text { ice calorimeter, } \\
\text { where time to } \\
\text { decrease the } \\
\text { temperature by } \\
10 \mathrm{~K} \text { across the } \\
\text { melting } \\
\text { temperature was } \\
\text { used as a measure } \\
\text { of the latent heat. }\end{array}$ & $\mathrm{n} / \mathrm{a}$ & $0^{\circ} \mathrm{C}$ calorie & $\begin{array}{c}\text { Rudberg } \\
{[69]} \\
1830\end{array}$ \\
\hline 508.15 & 7105 & $\mathrm{n} / \mathrm{a}$ & $\begin{array}{l}\text { Drop water } \\
\text { calorimeter }\end{array}$ & $\mathrm{n} / \mathrm{a}$ & $15^{\circ} \mathrm{C}$ calorie & $\begin{array}{c}\text { Person [70] } \\
1846 \\
\end{array}$ \\
\hline $\mathrm{n} / \mathrm{a}$ & 7086 & $\mathrm{n} / \mathrm{a}$ & $\begin{array}{l}\text { Drop water } \\
\text { calorimeter }\end{array}$ & $\mathrm{n} / \mathrm{a}$ & $15^{\circ} \mathrm{C}$ calorie & $\begin{array}{c}\text { Person [71] } \\
1848\end{array}$ \\
\hline \multirow[t]{2}{*}{500.45} & 7280 & $\mathrm{n} / \mathrm{a}$ & $\begin{array}{c}\text { Water calorimeter, } \\
\text { temperature } \\
\text { measurement } \\
\end{array}$ & $\mathrm{n} / \mathrm{a}$ & $15^{\circ} \mathrm{C}$ calorie & $\begin{array}{c}\text { Spring [72] } \\
1886\end{array}$ \\
\hline & 7254 & $\mathrm{n} / \mathrm{a}$ & $\begin{array}{c}\text { Water calorimeter, } \\
\text { double method of } \\
\text { mixtures }\end{array}$ & $\begin{array}{l}\text { L'etain de } \\
\text { Banca }\end{array}$ & $15^{\circ} \mathrm{C}$ calorie & $\begin{array}{l}\text { Pionchon } \\
\text { [53] } 1887\end{array}$ \\
\hline N/a & 7234.3 & $\mathrm{n} / \mathrm{a}$ & $\begin{array}{c}\text { Water calorimeter, } \\
\text { double method of } \\
\text { mixtures }\end{array}$ & $\mathrm{n} / \mathrm{a}$ & $15^{\circ} \mathrm{C}$ calorie & $\begin{array}{c}\text { Richards } \\
{[39,54]} \\
1893 \\
\end{array}$ \\
\hline \multirow[t]{2}{*}{503.15} & 6983 & $10 \%$ & Drop-Water & $\mathrm{n} / \mathrm{a}$ & $15^{\circ} \mathrm{C}$ calorie & $\begin{array}{c}\text { Robertson } \\
{[73]} \\
1902 \\
\end{array}$ \\
\hline & 7105 & $7 \%$ & $\begin{array}{c}\text { Electric } \\
\text { calorimeter, } \\
\text { cooling curve }\end{array}$ & $\mathrm{n} / \mathrm{a}$ & $15^{\circ} \mathrm{C}$ calorie & $\begin{array}{c}\text { Guinchant } \\
{[74]} \\
1907 \\
\end{array}$ \\
\hline 505.15 & 6981 & $10 \%$ & $\begin{array}{l}\text { Oberhoffer vacuum } \\
\text { calorimeter, which }\end{array}$ & $\mathrm{n} / \mathrm{a}$ & $15^{\circ} \mathrm{C}$ calorie & $\begin{array}{c}\text { Wüst et al. } \\
{[41]}\end{array}$ \\
\hline
\end{tabular}




\begin{tabular}{|c|c|c|c|c|c|c|}
\hline & & & $\begin{array}{l}\text { is Bunsen } \\
\text { calorimeter } \\
\text { combined with } \\
\text { electric vacuum } \\
\text { furnace. }\end{array}$ & & & 1918 \\
\hline $\mathrm{n} / \mathrm{a}$ & 6648 & $\mathrm{n} / \mathrm{a}$ & $\begin{array}{l}\text { Drop water } \\
\text { calorimeter } \\
\text { Tc=293.15 }\end{array}$ & $\begin{array}{c}99.79 \% \text { purity } \\
0.084 \% \mathrm{~Pb} \\
0.054 \% \mathrm{Cu}, \\
0.035 \% \mathrm{Fe} \\
0.021 \mathrm{Zn} \\
0.019 \% \mathrm{As}\end{array}$ & $15^{\circ} \mathrm{C}$ calorie & $\begin{array}{c}\text { Iitaka [43] } \\
1919\end{array}$ \\
\hline 505.15 & 7254 & $\mathrm{n} / \mathrm{a}$ & $\begin{array}{l}\text { Drop water } \\
\text { calorimeter }\end{array}$ & $99.98 \%$ & $15^{\circ} \mathrm{C}$ calorie & $\begin{array}{c}\text { Awbery and } \\
\text { Griffiths } \\
{[44]} \\
1926\end{array}$ \\
\hline $\mathrm{n} / \mathrm{a}$ & 7055 & $2 \%$ & $\begin{array}{l}\text { Drop water } \\
\text { calorimeter }\end{array}$ & $\begin{array}{l}99.989 \% \\
\text { purity with } \\
0.003 \% \mathrm{~Pb} \\
\text { and } 0.008 \% \\
\mathrm{Cu}\end{array}$ & $15^{\circ} \mathrm{C}$ calorie & $\begin{array}{c}\text { Umino [45] } \\
1926\end{array}$ \\
\hline $\mathrm{n} / \mathrm{a}$ & 6934 & $\mathrm{n} / \mathrm{a}$ & $\begin{array}{c}\text { Cooling and } \\
\text { heating curves }\end{array}$ & $\mathrm{n} / \mathrm{a}$ & $\begin{array}{c}\text { Thermochem } \\
\text { ical calorie }\end{array}$ & $\begin{array}{c}\text { Bartnev [55] } \\
1947\end{array}$ \\
\hline 505 & 7615 & $\mathrm{n} / \mathrm{a}$ & DSC & $\mathrm{n} / \mathrm{a}$ & $\begin{array}{l}\text { Thermochem } \\
\text { ical calorie }\end{array}$ & $\begin{array}{c}\text { Nagasaki } \\
\text { and Fujita } \\
{[60]} \\
1952\end{array}$ \\
\hline \multirow[t]{3}{*}{$\mathrm{n} / \mathrm{a}$} & 7074 & $3 \%$ & $\begin{array}{c}\text { Tammann thermal } \\
\text { analysis }\end{array}$ & $\mathrm{n} / \mathrm{a}$ & $15^{\circ} \mathrm{C}$ calorie & $\begin{array}{c}\text { Oelsen et al. } \\
{[58]} \\
1955\end{array}$ \\
\hline & 7199 & $\begin{array}{c}1.2 \% \\
( \pm 42 \mathrm{~J} / \mathrm{mol})\end{array}$ & $\begin{array}{l}\text { Drop-water- } \\
\text { scanning }\end{array}$ & $\mathrm{n} / \mathrm{a}$ & $15^{\circ} \mathrm{C}$ calorie & $\begin{array}{c}\text { Oelsen et al. } \\
{[59]} \\
1955\end{array}$ \\
\hline & 6864 & $\mathrm{n} / \mathrm{a}$ & $\begin{array}{l}\text { Drop-water- } \\
\text { scanning }\end{array}$ & $\mathrm{n} / \mathrm{a}$ & $15^{\circ} \mathrm{C}$ calorie & $\begin{array}{c}\text { Oelsen [56] } \\
1955\end{array}$ \\
\hline 505.05 & 7306 & $\mathrm{n} / \mathrm{a}$ & DTA & $\mathrm{n} / \mathrm{a}$ & $\begin{array}{c}\text { Thermochem } \\
\text { ical calorie }\end{array}$ & $\begin{array}{c}\text { Pascard [61] } \\
1959 \\
\end{array}$ \\
\hline \multirow[t]{3}{*}{505.15} & 7071 & $\mathrm{n} / \mathrm{a}$ & Water calorimeter & $\mathrm{n} / \mathrm{a}$ & $\begin{array}{l}\text { Thermochem } \\
\text { ical calorie }\end{array}$ & $\begin{array}{c}\text { Schürmann } \\
\text { and Träger } \\
{[75]} \\
1961\end{array}$ \\
\hline & 7075 & $\begin{array}{c}1 \% \\
( \pm 32 \mathrm{~J} / \mathrm{mol})\end{array}$ & DTA & $99.999 \%$ & $\begin{array}{l}\text { Thermochem } \\
\text { ical calorie }\end{array}$ & $\begin{array}{c}\text { Speros and } \\
\text { Woodhouse } \\
{[76]} \\
1963\end{array}$ \\
\hline & 7053 & $\pm 745 \mathrm{~J} / \mathrm{mol}$ & DTA, $10 \mathrm{C} / \mathrm{min}$ & $\begin{array}{l}\text { Chemically } \\
\text { pure (C.p.), } \\
\text { flattened } \\
\text { sample }\end{array}$ & $15^{\circ} \mathrm{C}$ calorie & $\begin{array}{l}\text { David [77] } \\
1964\end{array}$ \\
\hline 505.15 & 7241 & $2 \%( \pm 79.5)$ & DTA & $99.96 \%$ & $\begin{array}{l}\text { Thermochem } \\
\text { ical calorie }\end{array}$ & $\begin{array}{c}\text { Alpaut and } \\
\text { Heumann } \\
\text { [64] }\end{array}$ \\
\hline
\end{tabular}




\begin{tabular}{|c|c|c|c|c|c|c|}
\hline & & & & & & 1965 \\
\hline & 6886 & $2 \%$ & $\begin{array}{l}\text { DTA- Adiabatic } \\
\text { calorimeter }\end{array}$ & $99.999 \%$ & $\begin{array}{c}\text { Thermochem } \\
\text { ical calorie }\end{array}$ & $\begin{array}{c}\text { Chiotti et al. } \\
{[57]} \\
1966\end{array}$ \\
\hline & 7279 & $2.4 \%( \pm 87)$ & DSC & $\mathrm{n} / \mathrm{a}$ & $\begin{array}{c}\text { Thermochem } \\
\text { ical calorie }\end{array}$ & $\begin{array}{c}\text { Gwinup [78] } \\
1967 \\
\end{array}$ \\
\hline $\mathrm{n} / \mathrm{a}$ & 7406 & $6 \%$ & DSC Tian-Calvet & $\mathrm{n} / \mathrm{a}$ & $\begin{array}{l}\text { Thermochem } \\
\text { ical calorie }\end{array}$ & $\begin{array}{c}\text { Reznitskiy et } \\
\text { al. [62] } \\
1970\end{array}$ \\
\hline 505.15 & 7190 & $14 \%$ & $\begin{array}{l}\text { DSC DuPont } \\
\text { thermal analyser }\end{array}$ & $99.999 \%$ & $\mathrm{n} / \mathrm{a}$ & $\begin{array}{c}\text { Breuer and } \\
\text { Eysel [65] } \\
1982\end{array}$ \\
\hline \multirow[t]{2}{*}{504.9} & 7140 & $\begin{array}{c}1.2 \% \\
( \pm 40 \mathrm{~J} / \mathrm{mol})\end{array}$ & $\begin{array}{c}\text { Power } \\
\text { compensated DSC } \\
\text { (Perkin-Elmer) }\end{array}$ & $\mathrm{n} / \mathrm{a}$ & $\mathrm{n} / \mathrm{a}$ & \multirow[t]{2}{*}{$\begin{array}{c}\text { Höhne et al. } \\
{[66]} \\
1983\end{array}$} \\
\hline & 7190 & $\begin{array}{c}1 \%( \pm 30 \mathrm{~J} / \mathrm{m} \\
\mathrm{ol})\end{array}$ & $\begin{array}{l}\text { Heat Flux DSC } \\
\text { (DuPont) }\end{array}$ & $\mathrm{n} / \mathrm{a}$ & $\mathrm{n} / \mathrm{a}$ & \\
\hline 505.1 & 7200 & $\mathrm{n} / \mathrm{a}$ & $\begin{array}{c}\text { Adiabatic } \\
\text { calorimeter }\end{array}$ & $99.999 \%$ & $\mathrm{n} / \mathrm{a}$ & $\begin{array}{c}\text { Kano [79] } \\
1991\end{array}$ \\
\hline $\begin{array}{c}505.1 \pm 0 \\
01\end{array}$ & 7148.716 & $11 \%$ & Drop calorimetry & $\mathrm{n} / \mathrm{a}$ & $\mathrm{n} / \mathrm{a}$ & $\begin{array}{l}{[80]} \\
1992\end{array}$ \\
\hline 505.11 & 7140.407 & $8 \%$ & DSC & $\mathrm{n} / \mathrm{a}$ & $\mathrm{n} / \mathrm{a}$ & $\begin{array}{c}\text { Callanan } \\
\text { [81] } \\
1992\end{array}$ \\
\hline $\begin{array}{c}505.07 \pm 0 \\
.02\end{array}$ & 7179 & $\begin{array}{c}0.4 \% \\
( \pm 15 \mathrm{~J} / \mathrm{mol})\end{array}$ & DSC & $\begin{array}{c}99.9999 \% \\
0.07 \cdot 10^{-60} \% \mathrm{Al} \\
0.2 \cdot 10^{-60} \% \mathrm{Cr} \\
0.16 \cdot 10^{-60} \% \mathrm{Cu} \\
0.2 \cdot 10^{-60} \% \mathrm{Fe} \\
0.02 \cdot 10^{-60} \% \mathrm{Na}\end{array}$ & $\mathrm{n} / \mathrm{a}$ & $\begin{array}{c}\text { Grønvold } \\
{[63]} \\
1993\end{array}$ \\
\hline 505.05 & 7162 & $2 \%$ & Linseis DSC-L63 & $99.999 \%$ & $\mathrm{n} / \mathrm{a}$ & $\begin{array}{c}\text { Wolf et al. } \\
{[67]} \\
1994\end{array}$ \\
\hline 505.08 & 7291.168 & $1 \%$ & $\begin{array}{c}\text { DTA Perkin Elmer } \\
1020 \text { series }\end{array}$ & $99.99 \%$ & $\mathrm{n} / \mathrm{a}$ & $\begin{array}{c}\text { Zahra and } \\
\text { Zahra [68] } \\
1996\end{array}$ \\
\hline
\end{tabular}

\section{Methodology of current work}

\subsection{Experimental investigations}

\section{Adiabatic calorimetry}

The heat capacity of tin was measured in an automated vacuum adiabatic calorimeter combined with a computer-measuring system. The detailed device configuration and calorimetric technique are described in $[82,83]$. The temperature of the calorimeter was measured by a rhodium/iron resistance thermometer $\left(\mathrm{R}_{0} \sim 50 \Omega\right)$, which was calibrated to ITS-90 [84] over the temperature range 5-373 K. The temperature difference between the container and adiabatic shell was measured by 
an eleven-junction (copper $+0.1 \mathrm{wt} \%$ iron)-Chromel differential thermocouple. The adiabatic performance of the calorimeter was maintained by digital control using the computer-measuring system with an accuracy of $\pm 3 \cdot 10^{-3} \mathrm{~K}$. The error of measurements of the temperature of the container was estimated to be $\pm 2 \cdot 10^{-2} \mathrm{~K}$. The high vacuum inside the calorimetric cell was maintained by means of cryosorption provided with an efficient charcoal getter. The heat capacity of the substance was measured in the process of heating the sample. The mass of the sample was determined with a precision of $\pm 5 \cdot 10^{-2} \mathrm{mg}$ on a Mettler balance. The method of calorimetric determinations was checked by the measurement of the heat capacity of pure copper having the mass fraction 0.9995. The relative standard uncertainty of the heat capacity measurements, $\mathrm{u}_{\mathrm{r}}(\mathrm{Cp}, \mathrm{m})$, was 0.02 within temperature range $7-20 \mathrm{~K}, 0.007$ within temperature range $20-40 \mathrm{~K}$, 0.004 within temperature range $40-80 \mathrm{~K}$ and 0.002 above $80 \mathrm{~K}$.

\section{Enthalpy increment measurements}

Enthalpy increment measurements were carried out using an AlexSys 1000 isoperibol calorimeter. Samples of Sn (of 99.999\% purity) were dropped from room temperature into the hot calorimeter at a temperature where $\mathrm{Sn}$ is liquid, under a purified argon atmosphere (99.998\%). The heat effect is then equal to the sum of heat content of the sample and the heat of fusion.

$$
\int_{298}^{T} C_{p} d T+\Delta H_{f u s}
$$

Experiments were carried out at 600,650, 700, 750 and $800 \mathrm{~K}$. At each temperature the calorimeter was stabilized in order to get a stable baseline, and calibrated. The calibration was carried out using both $\mathrm{Al}_{2} \mathrm{O}_{3}$ sapphire supplied by NIST, and $99.999 \%$ Pt. From 3 to 7 drops were made to obtain the values for the calibration factors at each temperature. The typical mass of the samples of alumina (for calibration) and tin was $10-20 \mathrm{mg}$. The Calisto software was used for recording the signals from calorimeter and assessment of the results.

\subsection{Methodology of ab-initio calculations of $C_{p}$}

Thermodynamic calculations for grey and white tin were performed within the framework of density functional theory using the Vienna ab-initio simulation package VASP code [85-88]. The interaction between ions and electrons were described using the projector augmented-wave (PAW) method $[89,90]$ with fourteen highest electrons $\left(4 d^{10} 5 s^{2} 5 p^{2}\right)$ as valence electrons and a plane wave energy cut-off of $400 \mathrm{eV}$ for both phases. For calculation of exchange-correlation energy we used the Local Density approximation (LDA) with the scheme of Ceperley-Alder [91].

Two basis atoms with coordinates $(0,0,0)$ and $(a / 4, a / 4, a / 4)$ were chosen as the unit cell for the cubic diamond structure of $\alpha-\mathrm{Sn}$ (Fd-3m space group). The crystal structure of $\beta$-Sn with body-centered tetragonal Bravais lattice (I4_1/amd space group) also was set with two atoms 
in the basis at $(a / 8,7 a / 8, a / 4)$ and $(7 a / 8, a / 8,3 a / 4)$. The integration over the Brillouin zone was performed with an equivalent unit cell k-point grid or better than $16 \times 16 \times 16$ for $\alpha$-phase and $20 \times 20 \times 20$ for $\beta$-phase. All the calculations were carried out using the Methfessel-Paxton smearing (first order) [92] with a broadening of $\sigma=0.2 \mathrm{eV}$. The convergence criterion for electronic subsystem was chosen to be equal to $1 \mathrm{meV} /$ atom.

We calculated the heat capacity as a sum of the lattice contribution and the electronic one. The lattice heat capacity and enthalpy $S^{\mathrm{o}} 298.15$ were calculated in a quasi-harmonic approximation, which is required the calculation of phonon spectra with several volumes. Seven volumes were chosen in the range $-6 \ldots+6 \%$ of equilibrium volume with a $2 \%$ step. A small displacement method with a single atomic displacement value of $0.01 \AA$ was used to calculate the vibration frequencies in both phases for all the chosen volumes. The phonon spectra and the thermodynamic properties were calculated using the PHONOPY code [93]. The electron contribution was calculated in the Sommerfeld approximation, for which we calculated the electron density of states for both phases and found the number of states at the Fermi level. Note that the alpha phase is a semi-metal and the number of states at the Fermi level is negligible; therefore, the electron contribution for this phase was not calculated.

We carried out the convergence of the results depending on the size of the supercells and found that in the alpha phase convergence is achieved for a value of $4 \times 4 \times 4$. In the beta phase, we found a strong dependence on the size of the supercell and, in addition dynamic instability for all supercells, up to the size $5 \times 5 \times 5$. The greatest stability is observed on the supercell $4 \times 4 \times 4$, that is the reason of choosing it for calculating the thermodynamic properties. We will discuss the issue of dynamic stability and the choice of approximations in more detail in a forthcoming publication [94].

\subsection{Thermodynamic Models}

The modelling part was carried out in a similar way to that published earlier for $\mathrm{Pb}$ [3] following the recommendation of the Ringberg seminar [1] and using an evaluation procedure for $S^{\mathrm{o}}{ }_{298}$ using the approach of Voronin and Kutsenok for the obtaining a precise description of $C_{p}(T)$ [4].

The heat capacity at constant pressure representing a combination of the Einstein model and a polynomial correction term is described as:

$$
C_{p}=3 R\left(\frac{\theta_{E}}{T}\right)^{2} \frac{e^{\theta_{E} / T}}{\left(e^{\theta_{E} / T}-1\right)^{2}}+a T+b T^{2}+c T^{3}+d T^{4}
$$

Here the polynomial takes into account the anharmonic and electronic effects and the conversion from $C_{V}$ to $C_{p}$, etc. 
Integration of this equation allows us to obtain equations for other thermodynamic functions (with the inclusion of a term $3 / 2 R \theta_{\mathrm{E}}$ to $H$ and $G[2]$ ):

$$
\begin{gathered}
S=3 R\left[\frac{\theta_{E} / T}{\left(e^{\theta_{E} / T}-1\right)}+\ln \frac{e^{\theta_{E} / T}}{\left(e^{\theta_{E} / T}-1\right)}\right]+a T+\frac{b}{2} T^{2}+\frac{c}{3} T^{3}+\frac{d}{4} T^{4} \\
H=E_{0}+\frac{3}{2} R \theta_{E} \frac{\left(e^{\theta_{E} / T}+1\right)}{\left(e^{\theta_{E} / T}-1\right)}+\frac{a}{2} T^{2}+\frac{b}{3} T^{3}+\frac{c}{4} T^{4}+\frac{d}{5} T^{5} \\
G=E_{0}+\frac{3}{2} R \theta_{E}-3 R T \ln \frac{e^{\theta_{E} / T}}{\left(e^{\theta_{E} / T}-1\right)}-\frac{a}{2} T^{2}-\frac{b}{6} T^{3}-\frac{c}{12} T^{4}-\frac{d}{20} T^{5}
\end{gathered}
$$

In order to ensure that the crystalline phase does not become stable at very high temperatures the following equation is used to describe the thermodynamic properties of the crystalline phases above the melting point.

$$
C p=3 R\left(\frac{\theta_{E}}{T}\right)^{2} \frac{e^{\theta_{E} / T}}{\left(e^{\theta_{E} / T}-1\right)^{2}}+a^{\prime}+b^{\prime} T^{-6}+c^{\prime} T^{-12}
$$

with the coefficients $a^{\prime}, b^{\prime}$ and $c^{\prime}$ selected so that the heat capacity and its derivative are continuous at the melting point and merge with those of the liquid phase at some high temperature.

The thermodynamic properties of the liquid phase were represented using the two state model [78]. According to this model it is assumed that the liquid phase consists of the two types of atoms mixing ideally: atoms with vibrational motion with no translational degrees of freedom and atoms with translational motion. The atoms with vibrational motion can be thought of as representing a pure amorphous phase. This could also be expressed in terms of different energy states, an increase in space or degrees of translational and vibrational freedom available to the atoms.

For a given temperature the two types of atoms are in equilibrium so as to give a minimum in the total Gibbs energy. The relative amounts of these "translational" and "vibrational" atoms depend on the difference in Gibbs energy between them.

At each temperature a transition of atoms takes place from one state to another in order to achieve equilibrium with $\chi$ of translational atoms and $1-\chi$ fraction of vibrational atoms. The equilibrium value of $\chi$ is determined by the equation:

$$
\chi=\frac{e^{-\Delta G_{d i f} / R T}}{1+e^{-\Delta G / R T}}
$$

where $\Delta G_{\text {dif }}$ is the difference in Gibbs energy between the translational and vibrational atoms. The Gibbs energy of the vibrational atoms can be approximated by the Einstein equation, which includes additional parameters which may be optimized in order to obtain agreement with experimental data.

$$
G^{v i b}=E_{0}+\frac{3}{2} R \theta_{E}+3 R T \ln \frac{\left(e^{\theta_{E} / T}-1\right)}{e^{\theta_{E} / T}}+A+a T^{2}+b T^{3}
$$


The value for the Einstein temperature was taken initially to be the same as that of the crystalline phase. The parameters $A, a$ and $b$ were optimized. These parameters here refer only to the liquid phase. The Gibbs energy difference between the vibrational atoms and the translational atoms can be described as:

$$
\Delta G_{d i f}=G^{\text {trans }}-G^{v i b}=B+C T+D T \ln T \ldots
$$

Thus the total Gibbs energy $G^{L}$ will then be given by:

$$
G^{L}=G^{v i b}-R T \ln \left[1+e^{\left(-\Delta G_{d i f} / R T\right)}\right]
$$

The optimization of data for the liquid phase $(A, a, b, B, C$ and $D)$ was carried out using experimental data for the liquid phase.

\section{Voronin and Kutsenok method}

In order to evaluate $S^{0}{ }_{298}$ the heat capacity data were fitted using multiple Einstein functions as described in the work of Voronin and Kutsenok [4]. The method allows standard thermodynamic functions to be approximated with an accuracy corresponding to experimental measurements from $0 \mathrm{~K}$ up to the melting point.

Using this approach the experimental $C_{p}(T)$ data can be approximated using following equation

$$
C_{P}(T)=3 R \sum_{i} \alpha_{i} \frac{\left(\Theta_{i} / T\right)^{2} e^{\Theta_{i} / T}}{\left(e^{\Theta_{i} / T}-1\right)^{2}}
$$

Then an integration of the equation (11) with addition of $3 / 2 R \theta_{\mathrm{E}}$ (which corresponds to zero-point lattice vibration) leads to the following expressions for thermodynamic functions [6]:

$$
\begin{gathered}
S^{\mathrm{o}}(T)=3 R \sum_{i} \alpha_{i}\left(\frac{\Theta_{i} / T}{e^{\Theta_{i} / T}-1}-\ln \left(1-e^{-\Theta_{i} / T}\right)\right) \\
H_{T}^{\mathrm{o}}(T)-H_{0}^{\mathrm{o}}=\frac{3}{2} \theta_{E}+3 R \sum_{i} \alpha_{i} \Theta_{i}\left(e^{\Theta_{i} / T}-1\right)^{-1} \\
G_{T}^{\mathrm{o}}(T)-H_{0}^{\mathrm{o}}=\frac{3}{2} \theta_{E}+3 R \sum_{i} \alpha_{i} \Theta_{i}\left(e^{\Theta_{i} / T}-1\right)^{-1}-3 R T \sum_{i} \alpha_{i}\left(\frac{\Theta_{i} / T}{e^{\Theta_{i} / T}-1}-\ln \left(1-e^{-\Theta_{i} / T}\right)\right)
\end{gathered}
$$

where $\alpha_{i}, \Theta_{i}(i=1,2, .$.$) are parameters determined by fitting the experimental heat capacity data$ to equation (11). $\theta_{E}$ is the true Einstein temperature of Sn.

\section{Results and Discussion}

\subsection{Experimental results}




\section{Adiabatic measurements of $C_{p}$}

According to the Figure 3 the temperature dependence of the heat capacity of $\beta$-Sn in the temperature range 100-170 K could be defined only from the results of Naumov et al. [33], so these data required validation. Using adiabatic calorimetry, we obtained the values for the heat capacity of white tin in the temperature range 70-370 K. Figure 7 shows a comparison of the results obtained in this work with the works of Brönsted [21], Naumov et al. [33] (error 0.3\%), Kramer and Nölting [36] (error 1\%), the errors of our work correspond to $0.3 \%$. The raw data are listed in Appendix 1.

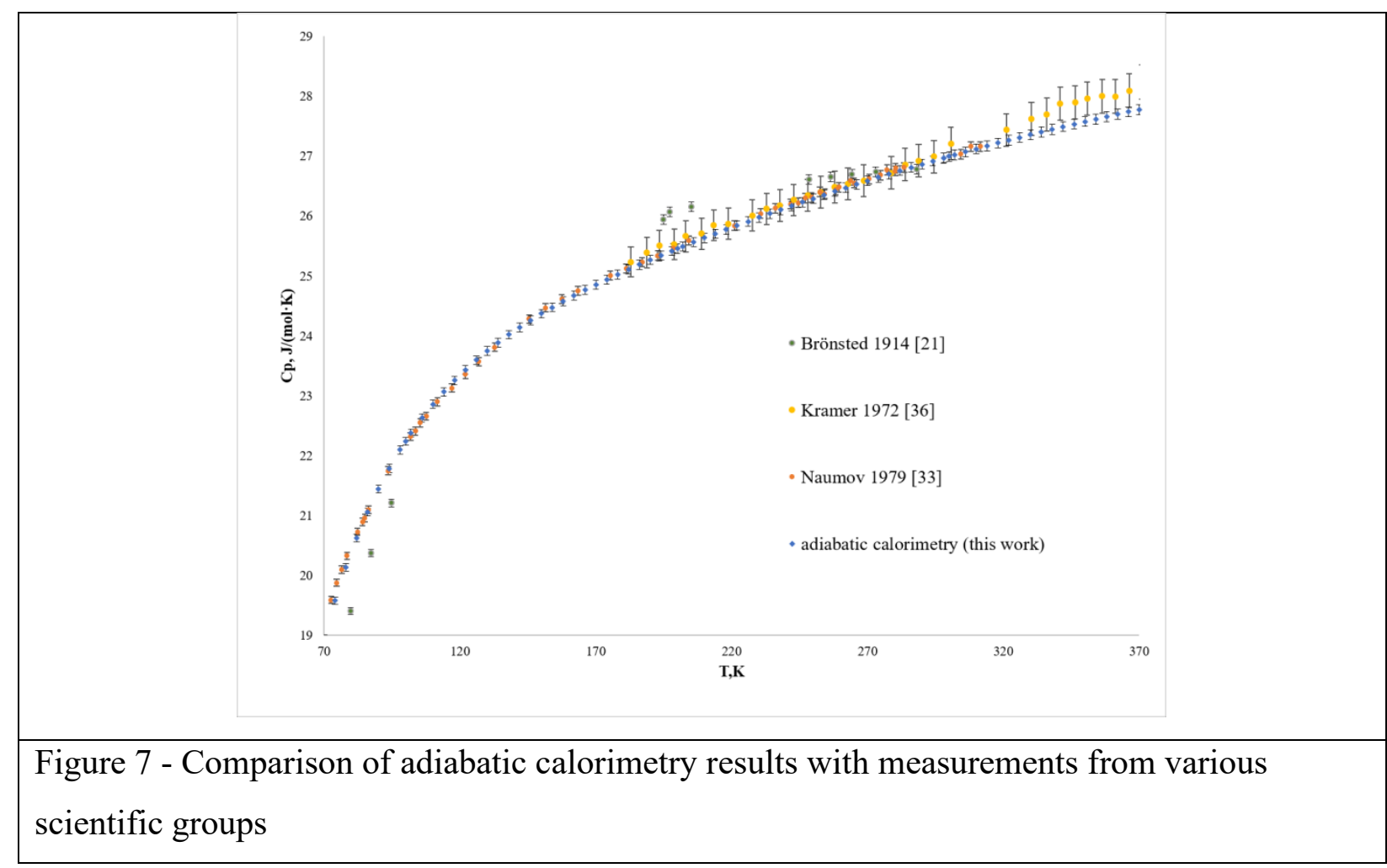

The obtained values of the heat capacity agree with the data from Naumov et al. [33] within the measurement error over the whole of the investigated temperature interval. Our experimental values and those of Naumov et al. [33] were given the same mathematical weight over the whole temperature range. Moreover, it should be noted that the data from Naumov et al. [33] are in good agreement with the data from Kramer and Nölting [36] up to $300 \mathrm{~K}$.

\section{Enthalpy drop results}

The experimental results of the enthalpy drop measurements for liquid tin obtained in this work are provided in Table 5 and Figure 8. These results are in a good agreement with the previous measurements.

Table 5. Values of enthalpy increment $H_{T}-H_{298}(\mathrm{~J} / \mathrm{mol})$ calculated from the drops of pure tin from room temperature to temperature of calorimeter T at $0.1 \mathrm{MPa}$ under Ar-atmosphere

\begin{tabular}{|c|c|c|c|}
\hline$T, \mathrm{~K}$ & Number of drops & $H^{\mathrm{o}}(T)-H^{\mathrm{o}}(298), \mathrm{J} / \mathrm{mol}$ & Error of measurement, \% \\
\hline
\end{tabular}




\begin{tabular}{|l|l|l|l|}
\hline 873.15 & 4 & 22104 & 1.38 \\
\hline 923.15 & 7 & 24115 & 1.54 \\
\hline 973.15 & 5 & 26351 & 1.06 \\
\hline 1023.15 & 5 & 27340 & 1.29 \\
\hline 1073.15 & 6 & 28013 & 1.84 \\
\hline
\end{tabular}

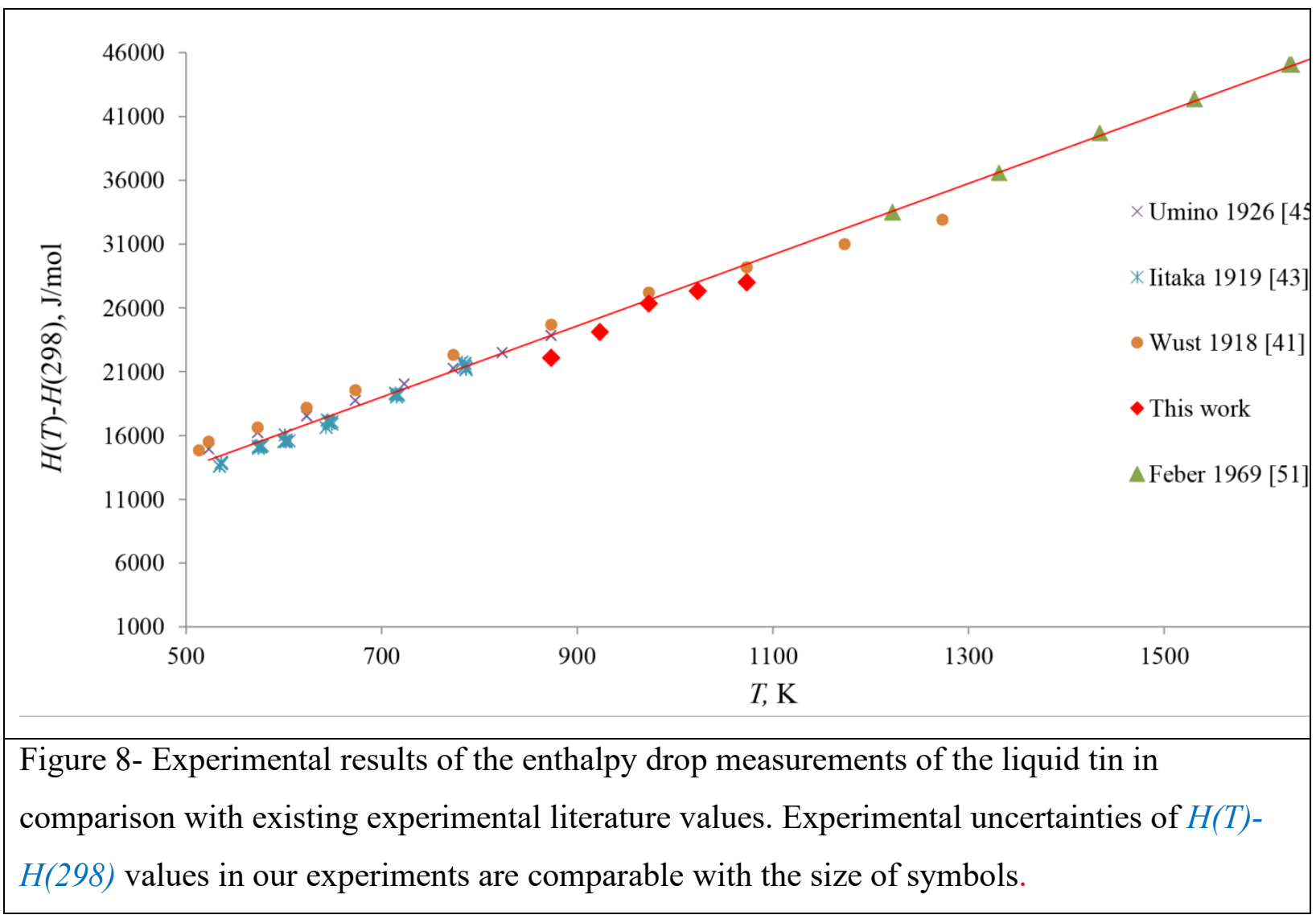

\subsection{Ab-initio calculations of $\mathrm{Cp}$}

Heat capacity of grey and white tin at a constant pressure were calculated in the temperature range from 0 to $300 \mathrm{~K}$. These calculations, therefore, fill a gap in the experimental heat capacity values for both phases. Theoretical calculations of the heat capacity of $\alpha$-tin $\left(C_{p}\right)$ in comparison with experimental measurements from Ref. [21, 23-25] are shown in Fig.9. We observe very good agreement between theory and experiment, especially in the low temperature range where the anharmonic effects are small. There is a small deviation in the range of high temperature due to increasing contribution from anharmonic effects. The values for standard entropy were also calculated from ab-initio methods and appeared to be for $\alpha$-tin $S_{298.15}^{0}=43.89 \mathrm{~J} / \mathrm{K} / \mathrm{mole}$, for $\beta$-tin $S^{\mathrm{o}}{ }_{298.15}=51.56 \mathrm{~J} / \mathrm{K} / \mathrm{mole}$. 


Figure 9 - Experimental and ab-initio data of the heat capacity for $\alpha$-tin for the temperature
range: 0-300 K.

Figure 10 represent full and partial contributions to heat capacity at a constant pressure $\left(C_{p}\right)$ for $\beta$ tin phase. Our calculations accurately reproduce experimental results in the whole temperature range (see the insert picture in Figure 10).

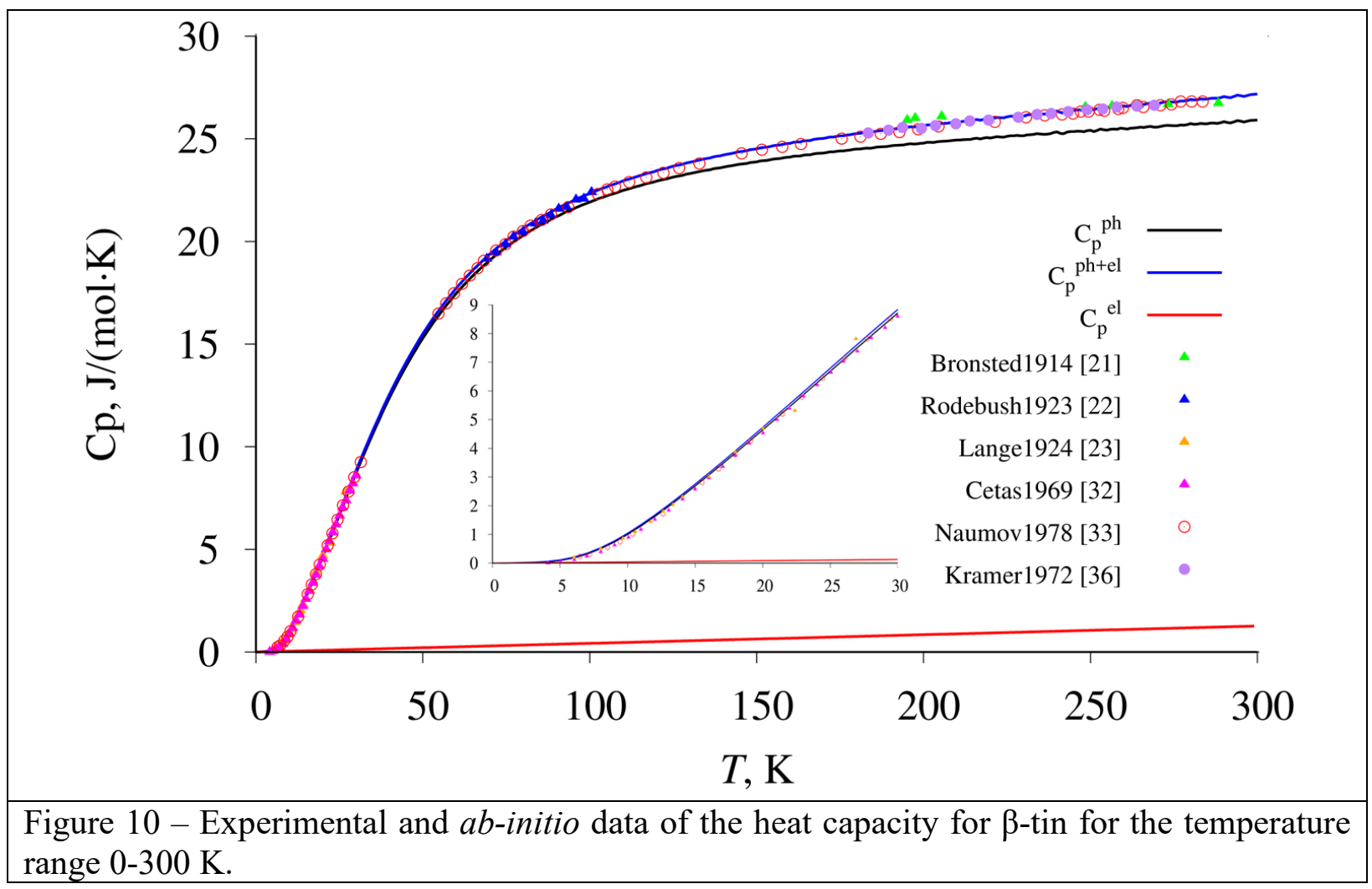

\subsection{Evaluation of $S^{o}{ }_{298.15}$}

Grey $(\alpha) \operatorname{tin}$ 
An experimental investigation of the temperature dependence of $C_{p}$ for $\alpha$-tin is presented only in four works: Brönsted [21], Lange [23], Hill [24], Webb and Wilks [25]. So, all of these experimental points were included in our calculation, but with different mathematical weights. We attempted to extrapolate data from Lange [23] with an Einstein function (Fig. 11, orange line) and to compare this with his own extrapolation. Our extrapolation curve is in good agreement at temperatures above $200 \mathrm{~K}$ with the Brönsted [21] experimental points taking into account the likely error of the experimental results assumed to be about $1 \%$. Therefore, in this temperature range, the data of Brönsted [21] were assigned the maximum mathematical weight. The heat capacity values obtained by extrapolation of the data of Lange [23] were not taken into account in the calculation. In the low temperature range the data from Lange [23], Hill [24], Webb and Wilks [25] were given the maximum mathematical weight, but the data from Brönsted [21] were given lower weight $(\mathrm{w}=0.5)$

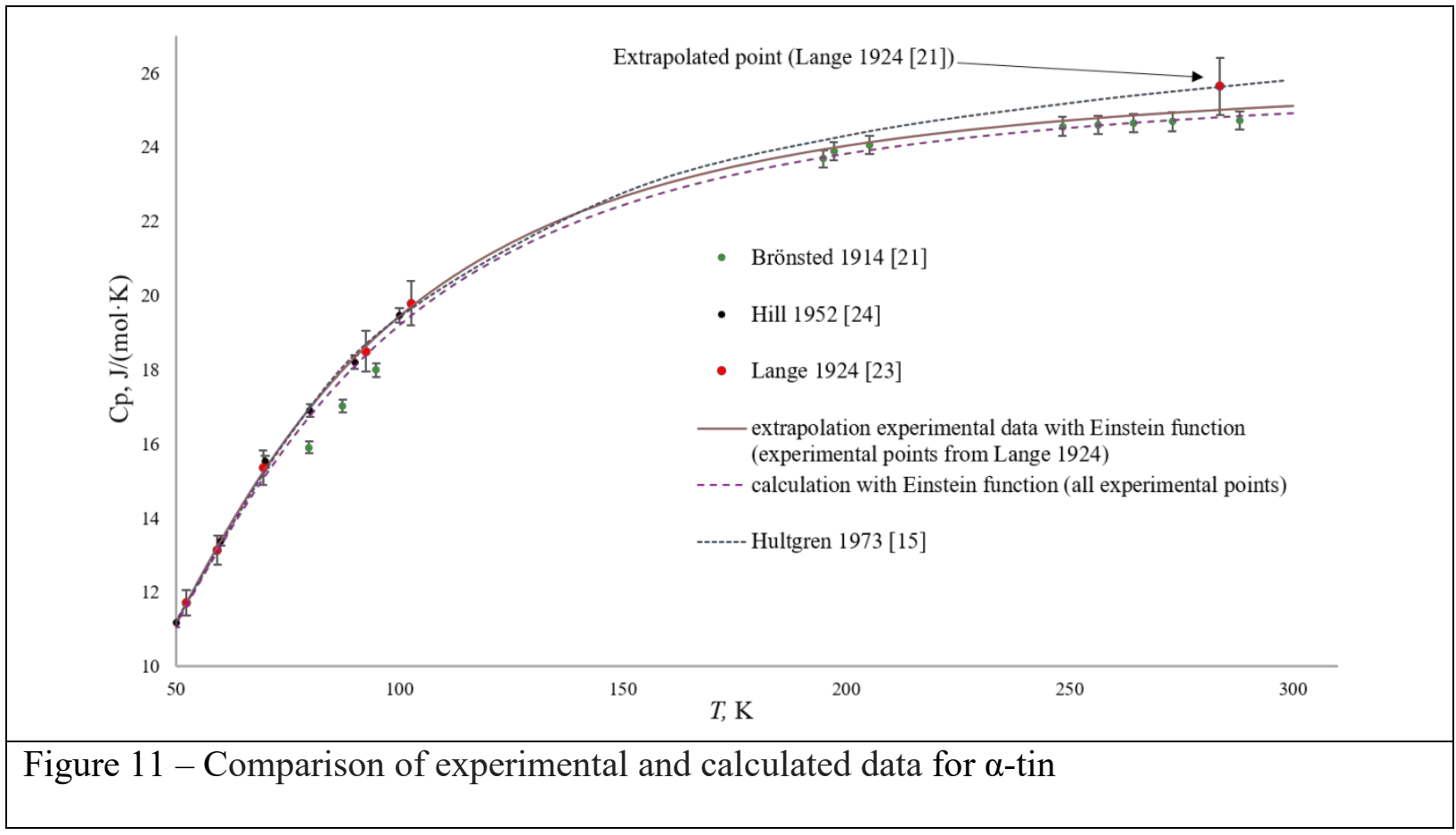

The parameters obtained as a result of the joint approximation of the low temperature data are listed in Table 6 and the calculated thermodynamic functions are listed in Table 7. The unknown parameters $\alpha_{i}$ and $\Theta_{i}$ of Eq. (11) were determined by the solution of a system of nonlinear equations using a least squares method embodied in the software package "Cpfit" available from the site [5]. All the parameters are given with an excess number of significant digits as the use of rounded values of $\alpha_{i}$ and $\Theta_{i}$ may lead to greater uncertainty in the calculated heat capacity values in comparison with the experimental uncertainties. A detailed description of the calculation 
procedure and uncertainty estimation is given in the Manual which is available from the same address [5].

As can be seen from Table 7, there is an excellent agreement between the ab-initio calculated standard entropy and the assessed value derived with two Einstein function.

Table 6 Parameters for the joint approximation $C_{p}(T)$ data for $\alpha$-tin (*)

\begin{tabular}{|l|l|l|l|l|l|l|}
\hline \multirow{2}{*}{$i$} & \multirow{2}{*}{$\alpha_{i}$} & \multirow{2}{*}{$\Theta_{i}$} & \multicolumn{2}{|l|}{ Standard deviation } & \multicolumn{2}{l|}{ Max deviation } \\
\cline { 3 - 7 } & & absolute & relative $\%$ & $\begin{array}{l}\text { absolute, } \\
\mathrm{J} /(\mathrm{mol} \cdot \mathrm{K})\end{array}$ & relative $\%$ \\
\hline 1 & $0.664046 \pm 0.01$ & $238.552 \pm 5$ & 0.112 & 16.12 & $\begin{array}{l}0.1924 \text { at } \\
22.35 \mathrm{~K}\end{array}$ & $\begin{array}{l}67.83 \% \text { at } \\
7 \mathrm{~K}\end{array}$ \\
\hline 2 & $0.369633 \pm 0.02$ & $67.1438 \pm 2$ & & & & \\
\hline
\end{tabular}

Table 7 Approximated value of standard thermodynamic functions of $\alpha$-Sn at $298.15 \mathrm{~K}$.

\begin{tabular}{|c|c|c|c|c|c|}
\hline \multicolumn{3}{|c|}{ Calculated value } & \multicolumn{3}{|c|}{ Standard deviation (absolute) } \\
\hline$C_{p, 298.15}$ & $S_{298.15}^{\mathrm{o}}$ & \multirow{2}{*}{$\begin{array}{c}H^{\mathrm{o}}{ }_{298.15}-H^{\mathrm{o}} \\
\mathrm{J} / \mathrm{mol}\end{array}$} & $C_{p, 298.15}$ & $S_{298.15}^{\mathrm{o}}$ & \multirow{2}{*}{$\begin{array}{c}H^{\mathrm{o}} 298.15-H^{\mathrm{o}} 0 \\
\mathrm{~J} / \mathrm{mol}\end{array}$} \\
\hline \multicolumn{2}{|c|}{$\mathrm{J} /(\mathrm{mol} \cdot \mathrm{K})$} & & \multicolumn{2}{|c|}{$\mathrm{J} /(\mathrm{mol} \cdot \mathrm{K})$} & \\
\hline 24.89 & 43.68 & 5674.4 & 0.05 & 0.07 & 7.7 \\
\hline
\end{tabular}

White $(\beta)$ tin

\subsubsection{Analysis of the low temperature data}

The data from the publications of Naumov et al. [33], Lange [23], Rodebush [22], Zavaritskii [29], Yaqub [35], O’Neal [31], Keesom [34] and our adiabatic calorimetry data were taken into consideration during the analysis of the low temperature data. In the temperature range up to $298.15 \mathrm{~K}$, the results of our work and those of Naumov et al. [33] overlap in terms of the temperature range studied, and are sufficient for the calculation: from the point of transition to the normal state up to $370 \mathrm{~K}$. Moreover, these data are the only ones in the temperature range 100-200 K. So, our data together with those of Naumov et al. [33] should be taken as the most reliable and in the case of any discrepancies with the other works, assigned the maximum mathematical weight.

Table 8 Parameters for the joint approximation $C_{p}(T)$ data for $\beta$-tin (*). 


\begin{tabular}{|l|l|l|l|l|l|l|}
\hline \multirow{2}{*}{$I$} & \multirow{2}{*}{$\alpha_{i}$} & \multirow{2}{*}{$\Theta_{i}$} & \multicolumn{2}{|c|}{ Standard deviation } & \multicolumn{2}{c|}{ Max deviation } \\
\cline { 5 - 7 } & & Absolute & relative \% & $\begin{array}{l}\text { absolute, } \\
\mathrm{J} /(\mathrm{mol} \cdot \mathrm{K})\end{array}$ & relative \% \\
\hline 1 & $0.175386 \pm 0.01$ & $1264.02 \pm 44$ & 0.06603 & 18.31 & $\begin{array}{l}0.4911 \text { at } \\
32.7 \mathrm{~K}\end{array}$ & $\begin{array}{l}99.91 \% \text { at } \\
3.076 \mathrm{~K}\end{array}$ \\
\hline 2 & $0.227599 \pm 0.06$ & $251.216 \pm 22$ & & & & \\
\hline 3 & $0.604408 \pm 0.04$ & $123.98 \pm 8$ & & & & \\
\hline 4 & $0.224656 \pm 0.03$ & $50.4622 \pm 3$ & & & & \\
\hline
\end{tabular}

(*) Data from Naumov [33], Kramer [36] (180-320K), Zavaritskii [29] and our adiabatic experiment are given a weight $1(w=1)$, data from Lange [23], Rodebush [22], Keesom [34] are given a weight $0.5(w=0.5)$, data from Yaqub [35], O’Neal [31] and Kramer [36] (above 320K) are given a weight $0.01(w=0.01)$.

Table 9. Approximated value of standard thermodynamic functions of $\beta$-Sn at 298.15K.

\begin{tabular}{|c|c|c|c|c|c|c|}
\hline & & Calculate & lue & Stan & ard deviatic & absolute) \\
\hline & $C_{p, 298.15}$ & $S^{\mathrm{o}}{ }_{298.15}$ & $H^{\mathrm{o}}{ }_{298.15}-H^{\mathrm{o}}{ }_{0}$ & $C_{p, 298.15}$ & $S_{298.15}^{0}$ & $H^{\mathrm{o}}{ }_{298.15}-H^{\mathrm{o}} 0$ \\
\hline & & $1 \cdot \mathrm{K})$ & $\mathrm{J} / \mathrm{mol}$ & $\mathrm{J} /(\mathrm{n}$ & $1 \cdot \mathrm{K})$ & $\mathrm{J} / \mathrm{mol}$ \\
\hline 1 & 26.96 & 51.12 & 6316.5 & 0.01 & 0.02 & 1.0 \\
\hline 2 & 26.97 & 51.13 & 6317.6 & 0.006 & 0.03 & 1.1 \\
\hline & $\begin{array}{l}\text { Commen } \\
\text { 1. Low tem } \\
\text { Yaqub [ } \\
\text { 2. Joint an } \\
\text { Rodebus } \\
\text { calorime }\end{array}$ & $\begin{array}{l}\text { ature datc } \\
\text { O'Neal } \\
\text { sis of lov } \\
\text { 22], Zava } \\
\text { data (70. }\end{array}$ & $\begin{array}{l}\text { aumovet al. } \\
\text { T3 } \\
\text {, Keesom [34], high temper } \\
\text { kii [29], Yaqub } \\
\text { K), Kramer [3 }\end{array}$ & $\begin{array}{l}\text { Lange [23], } \\
\text { adiabatic } \\
\text { re data: } N \\
\text { ], O'Neal [ }\end{array}$ & $\begin{array}{l}\text { debush [2. } \\
\text { lorimetry a } \\
\text { mov et al. } \\
\text { 7, Keesom }\end{array}$ & $\begin{array}{l}\text { Zavaritskii [29], } \\
\text { (70-300K) } \\
\text { 3], Lange [23], } \\
\text { ], our adiabatic }\end{array}$ \\
\hline
\end{tabular}

One useful possibility emerging from the approximation of $C_{p}(T)$ using the combination of Einstein functions is that it provides an estimate of the entropy and enthalpy of the $\alpha-\beta$ transition. By using Eq.12 and the parameters from Tables 6 and 8, the temperature dependence $S^{\circ}(T)$ for both solid phase can be calculated and the difference of entropy at the temperature of reversible phase transition is determined. According to our calculation, it's equal to $7.603 \mathrm{~J} /(\mathrm{mol} \cdot \mathrm{K})$ at 286.35 $\mathrm{K}$ and $\Delta_{\mathrm{tr}} H=2177 \mathrm{~J} / \mathrm{mol}$.

\subsection{SGTE modelling}


$\alpha-$ tin

It is known that it is not possible to describe the heat capacity of crystalline Ge and Si using one Einstein temperature. This suggests that the diamond phase (in our case $\alpha$-tin) should be described using two Einstein temperatures for consistency [95]. For this reason equation (2) was modified as follows:

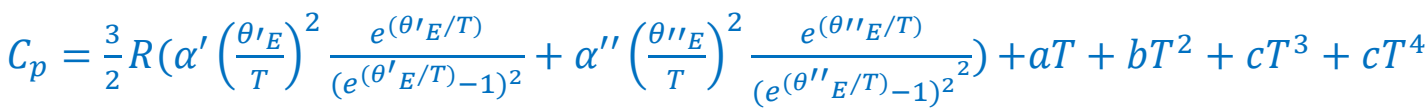

Where $\alpha^{\prime}+\alpha^{\prime \prime}=1$

Due to the fact that there are no experimental data from $100 \mathrm{~K}$ up to the temperature of the transformation for the present assessment we used low temperature experimental data and heat capacity data obtained from ab-initio calculations. We had to take into account that $C_{p}$ obtained from ab-initio calculations always have lower values than the experimental values. In order to take this into account we considered the values estimated by Lange [23] as the upper limit and also results from the approximations we obtained in the present work, when analyzing the values of $S^{\mathrm{o}}{ }_{298}$. The stability of grey tin and conditions of the transformation remain an open question and the problem will be discussed in more detail in the Part II of this paper. At the moment we made a decision to model the $E_{0}$ parameter of the Gibbs energy in the way that grey tin is stable at low temperature and white tin is stable at higher temperature. We used differences in energies which were obtained from ab-initio calculations in order to estimate the $E_{0}$ parameter for the Gibbs energy function. The calculated heat capacity is presented on Figure 12. The calculated temperature and heat of transformation from $\alpha$-tin to $\beta$-tin are $286.35 \mathrm{~K}(13.2 \mathrm{C})$ and $2101 \mathrm{~J} / \mathrm{mol}$ respectively. The calculated value of $S^{\mathrm{o}}{ }_{298}$ is $43.68 \mathrm{~J} /(\mathrm{mol} \cdot \mathrm{K})$, which is in agreement with the estimated value obtained by ab-initio and by fitting $C_{p}(T)$ data with sum of two Einstein functions without strict requirement $\alpha^{\prime}+\alpha^{\prime \prime}=1$ (according to Table 6, $a_{1}+a_{2}=1.03 \pm 0.02$ ). 


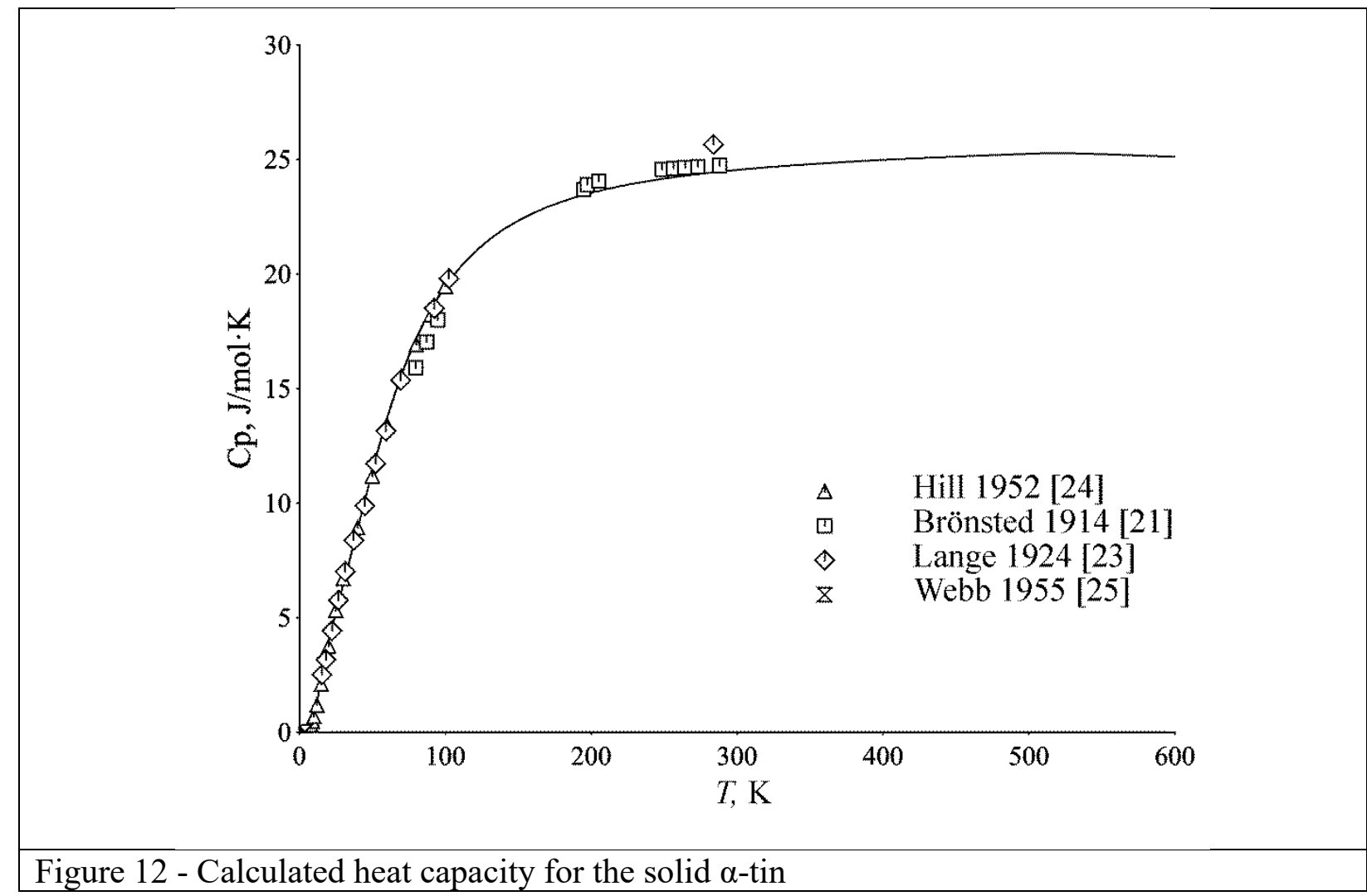

$\beta$-tin

In order to determine parameters of the model for $\beta$-tin in the high temperature interval (200$500 \mathrm{~K}$ ), higher weight were given to the data from Kramer and Nölting [36] and Naumov [33]. Zero weight was given to the data from Brönsted [21], Klinghardt [37] and Bartenev [38]. In the intermediate interval high weight was given to our experimental data and the data from Naumov [33]. Smaller weight was given to the data from Lange [23] and Rodebush [22]. The evaluated value for $S^{\mathrm{o}}{ }_{298}$ was used as a fixed point. The first round of optimization of the parameters $a, b$ and $c$ and the Einstein temperature (in the equation 2) showed that we couldn't obtain reasonable fit down to $100 \mathrm{~K}$. For this reason a similar approach using 2 Einstein temperatures was used. The model we obtained allowed us to have a reasonable description for $C_{p}$ down to $20 \mathrm{~K}$ (Figure13ac). A comparison of the calculated values and results of enthalpy drop measurements showed reasonable agreement with the existing data of Awbery and Griffiths [44], Umino [45] and Genot [46] (Figure 14a-c).

In order to avoid stabilization of the solid phase above melting point the parameters $a^{\prime}, b^{\prime}, c^{\prime}$ of the equation 6 were optimized. This required the selection of some constant heat capacity for very high temperatures, which was selected within the range of values of the heat capacity of liquid phase above the melting point. The parameter $a^{\prime}$ is equal as the difference between $3 R$ and selected heat capacity. The parameters $b^{\prime}$ and $c^{\prime}$ were obtained knowing values for the heat capacity and its derivative at the melting point. 


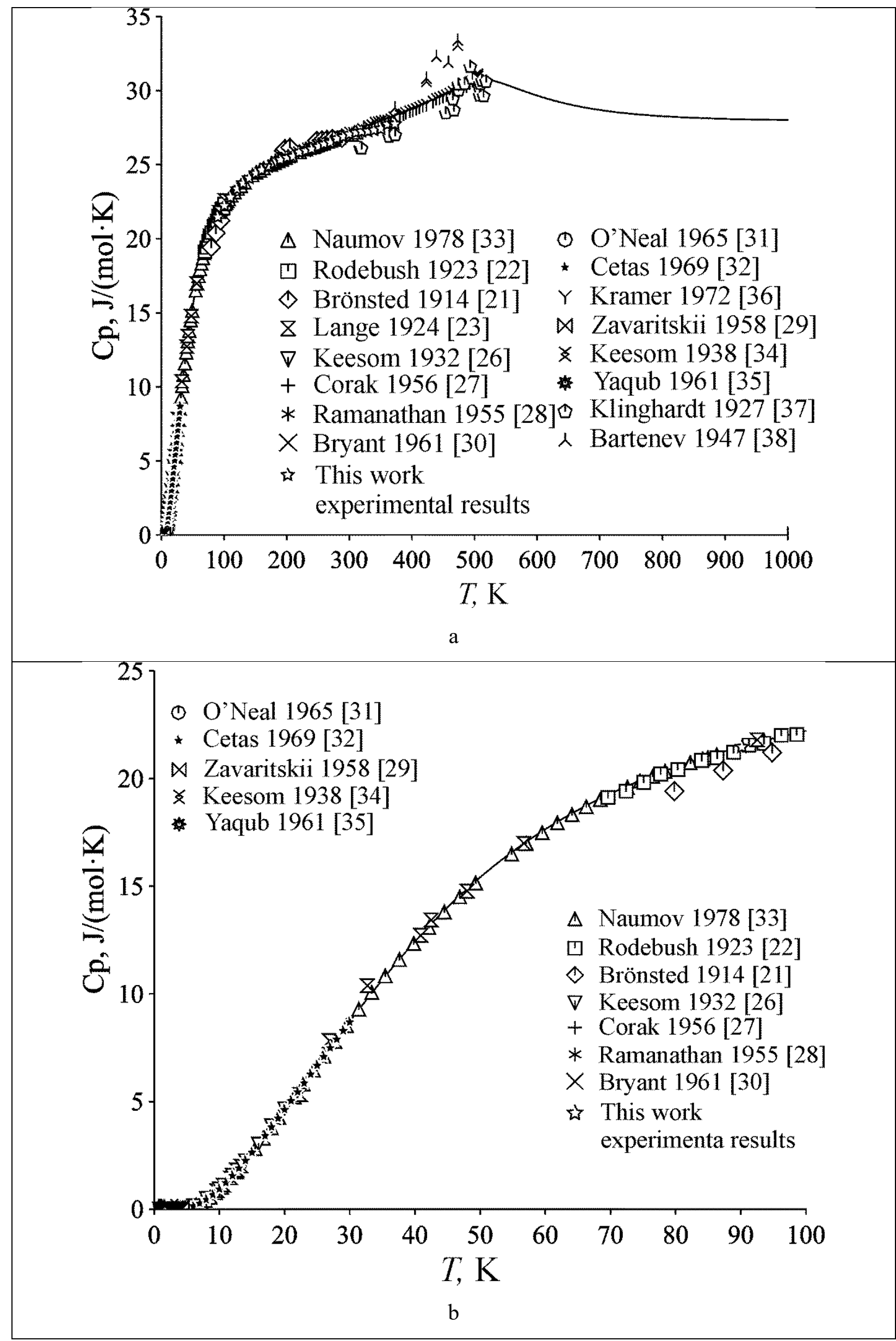



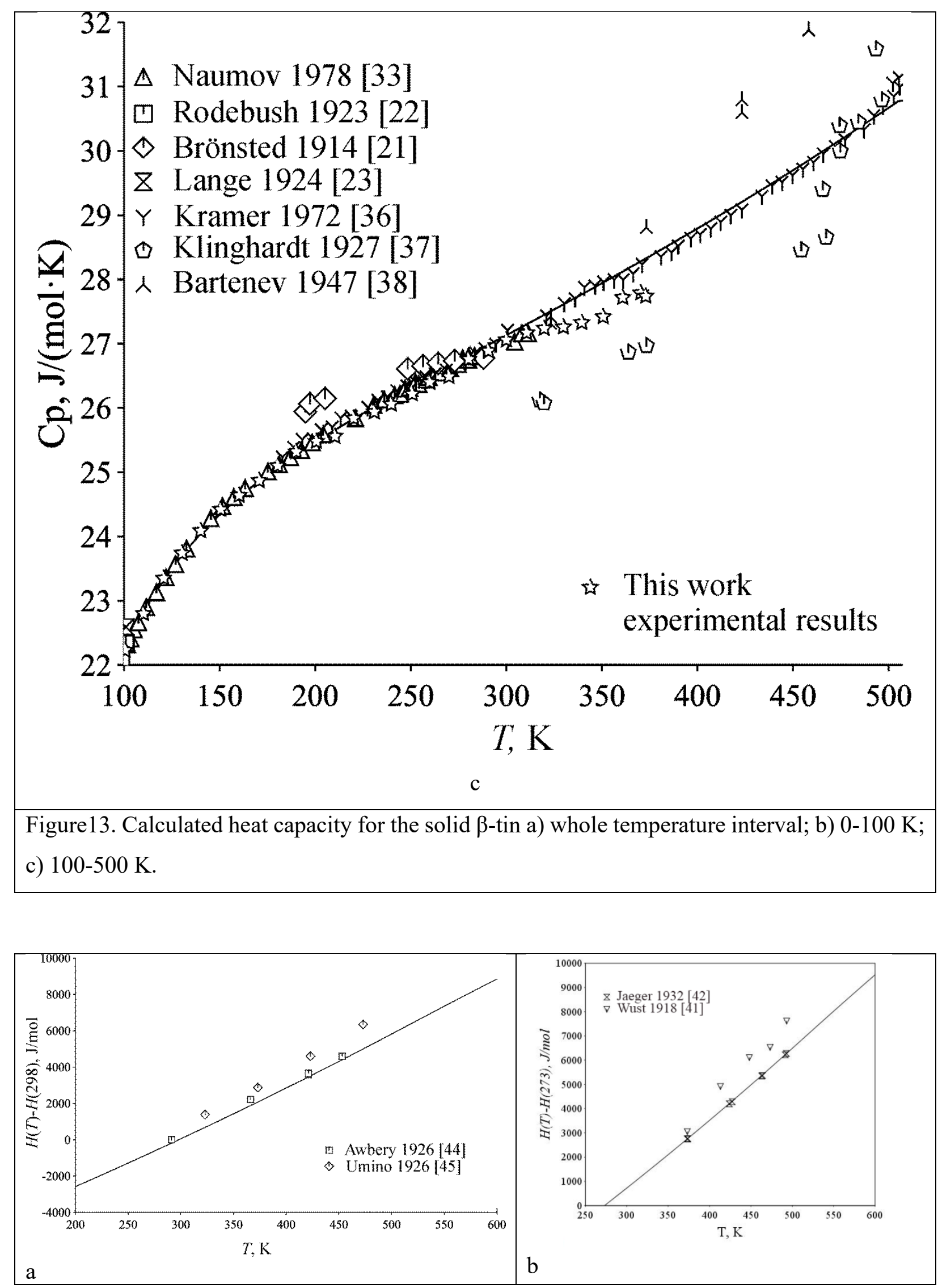


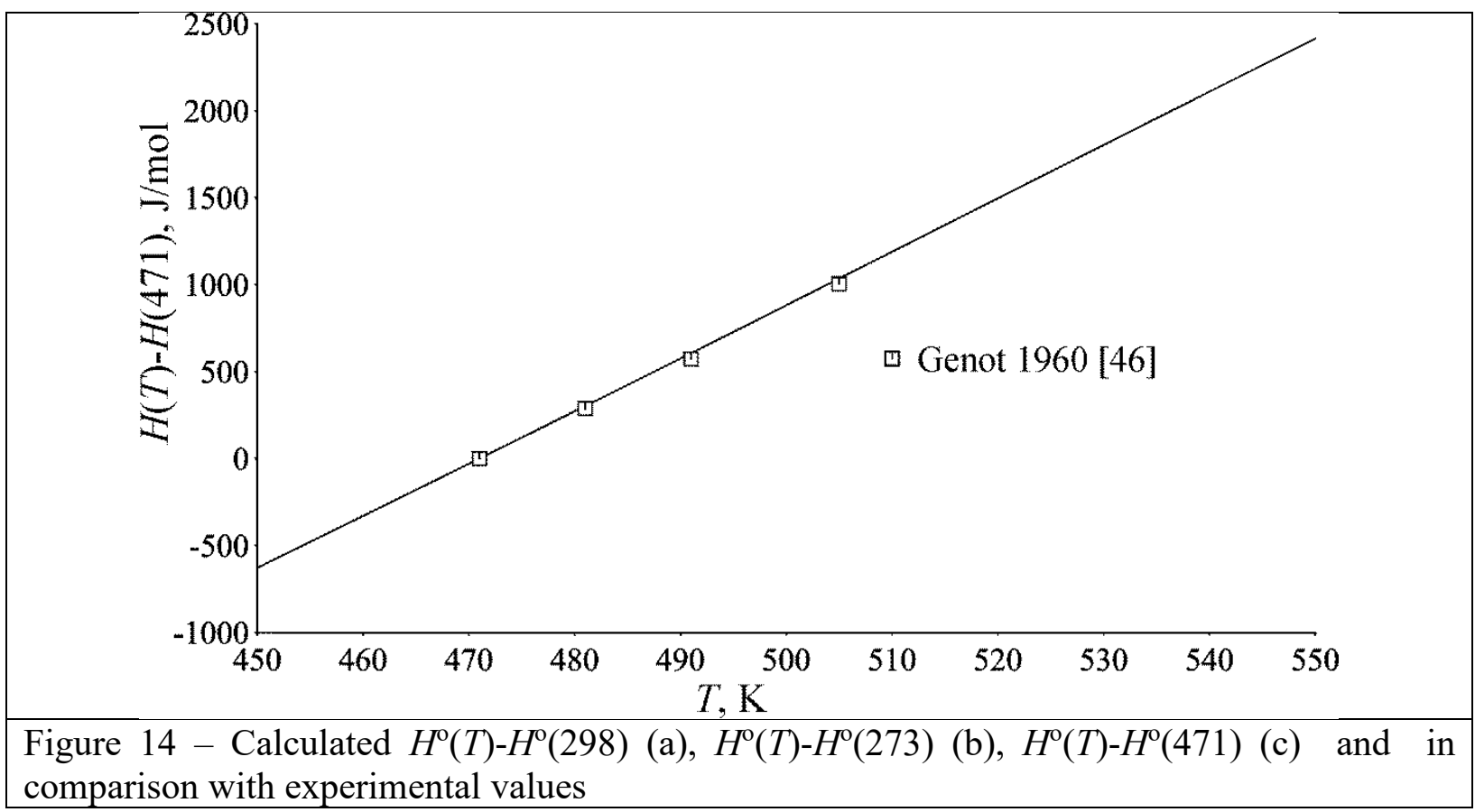

The calculated value for $S_{298}^{\mathrm{o}}=51.12 \mathrm{~J} /(\mathrm{mol} \mathrm{K})$, which is equal to the evaluated value derived with a combination of four Einstein functions (Table 8).

\section{Liquid phase}

There is no reason to use two Einstein temperatures for the description of data for the liquid phase. For this reason we evaluated a single value of $107.02 \mathrm{~K}$ for the Einstein temperature using the data for the $\beta$-tin. Using this value the parameters for the liquid phase were optimized putting more weight on the temperature of fusion and enthalpy of fusion data. Of the $C_{p}$ data, more weight was given to the data from Bartenev [55], Heffan [48] and Chen and Turnbull [50]. At the first step of the optimization the parameters $B$ and $C$ in the equation (9) were taken to be equal to the enthalpy and entropy of fusion as a starting point. The parameter $A$ was taken as a free parameter for optimization. Then all three parameters $A, B$ and $C$ were optimized together. It appeared that for the description of the liquid phase no other parameters were needed to fit the existing experimental data. The calculated value for the enthalpy of fusion is $7187 \mathrm{~J} / \mathrm{mol}$ which is identical to the value derived from the measurements carried by Grønvold [63]. The entropy of fusion is calculated to be equal to $14.224 \mathrm{~J} /(\mathrm{mol} \cdot \mathrm{K})$ and temperature of fusion is equal to $505.08 \mathrm{~K}$ in comparison to $505.078 \mathrm{~K}$ according to ITS-90. The comparison of calculated values with the experimental $C_{p}$ and enthalpy drop measurements are presented in Figure 15 (a,b,c). Values of $\chi$ from the two-state model were calculated over the entire temperature range and presented on figure 16 . The complete heat capacity curve is presented in figure 17. 


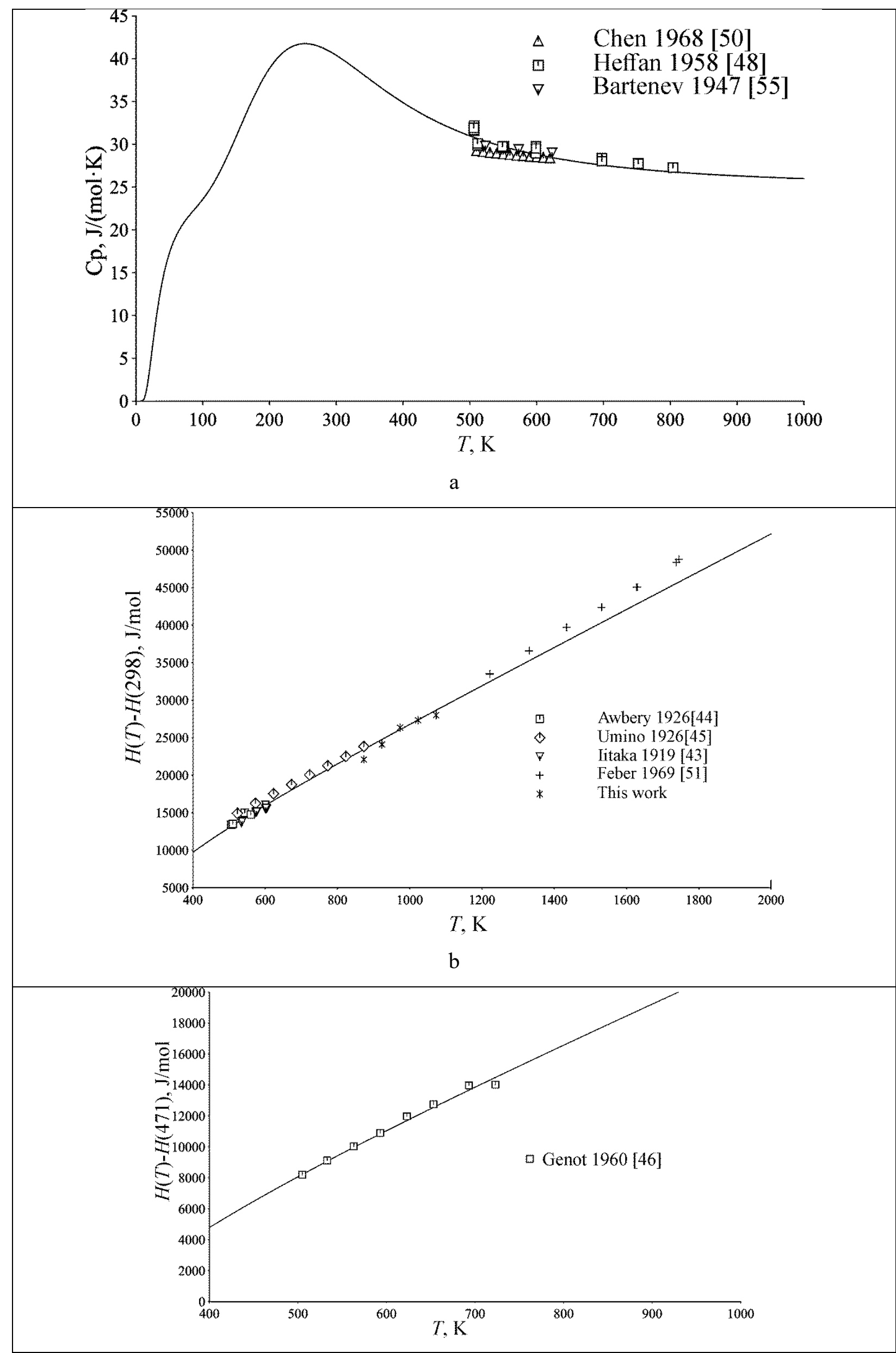


Figure 15 - a) Calculated heat capacity in comparison with the experimental data from the literature $[48,50,55]$; b) calculated enthalpy increments for the liquid phase in comparison with literature data [43-45,51] and experiments undertaken in the present work; c) calculated enthalpy increments for the liquid phase in comparison with data from Genot [46]
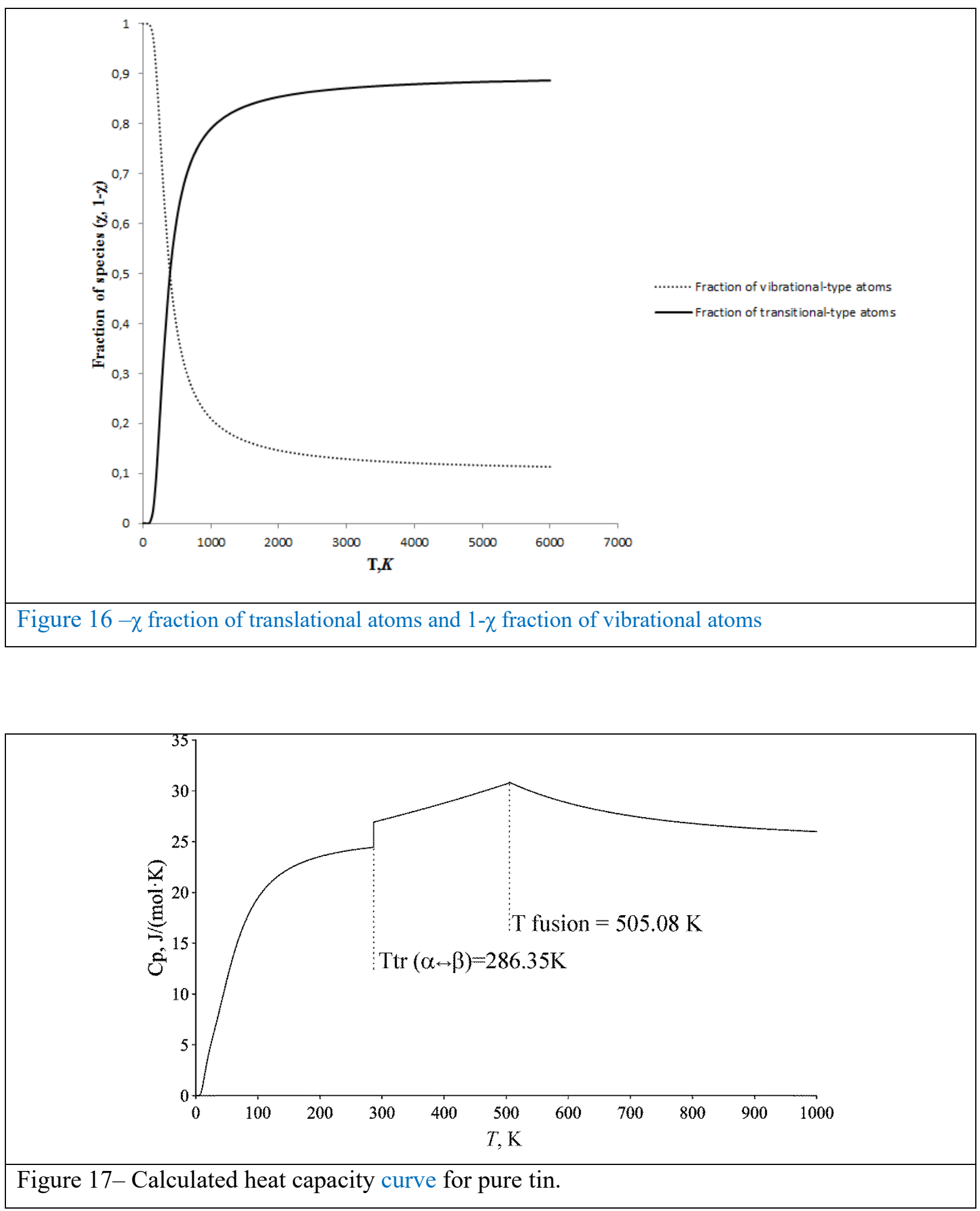
Table 10. Assessed parameters for pure tin

\begin{tabular}{|c|c|}
\hline Phase & \\
\hline$\alpha$-tin & 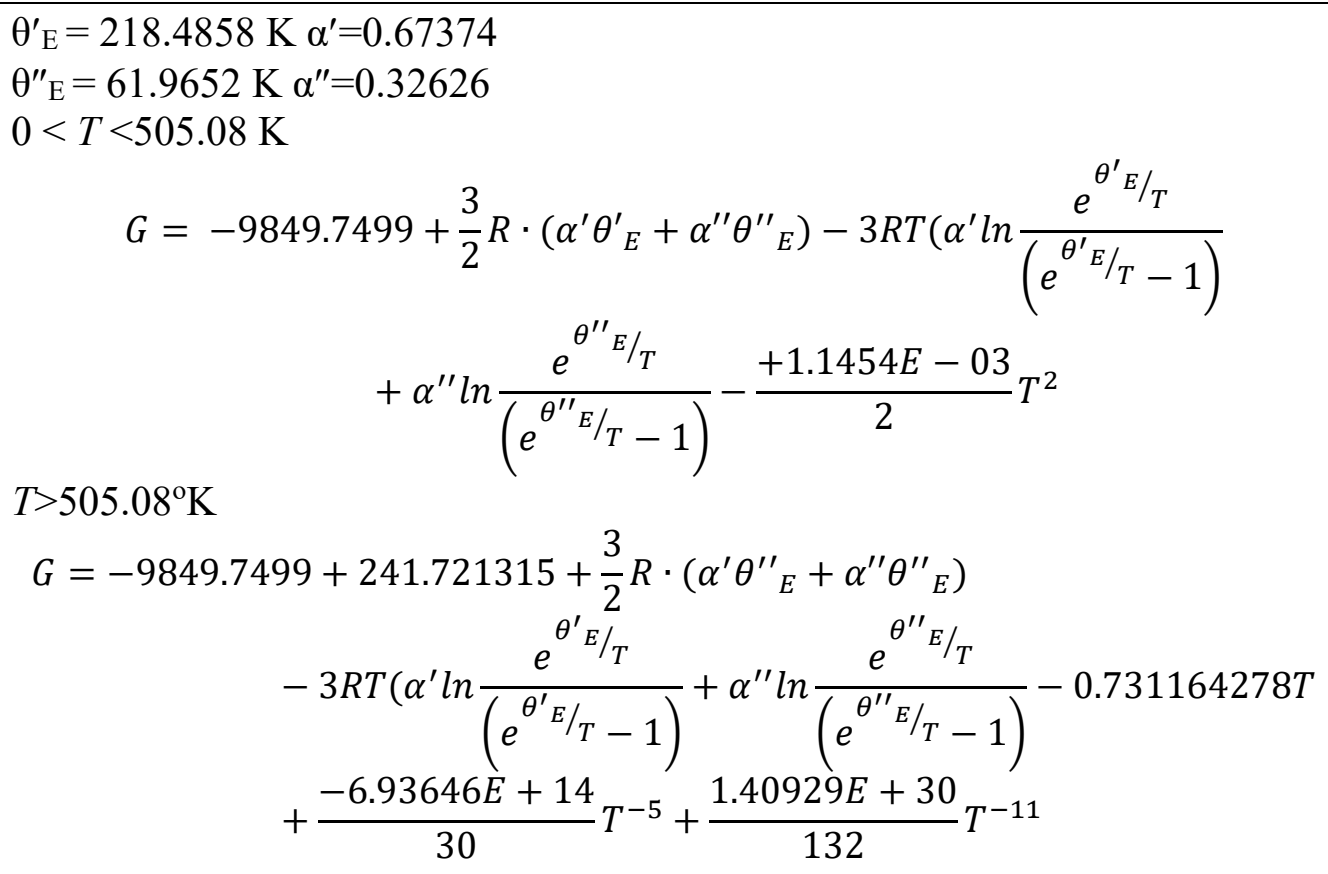 \\
\hline$\beta$-tin & 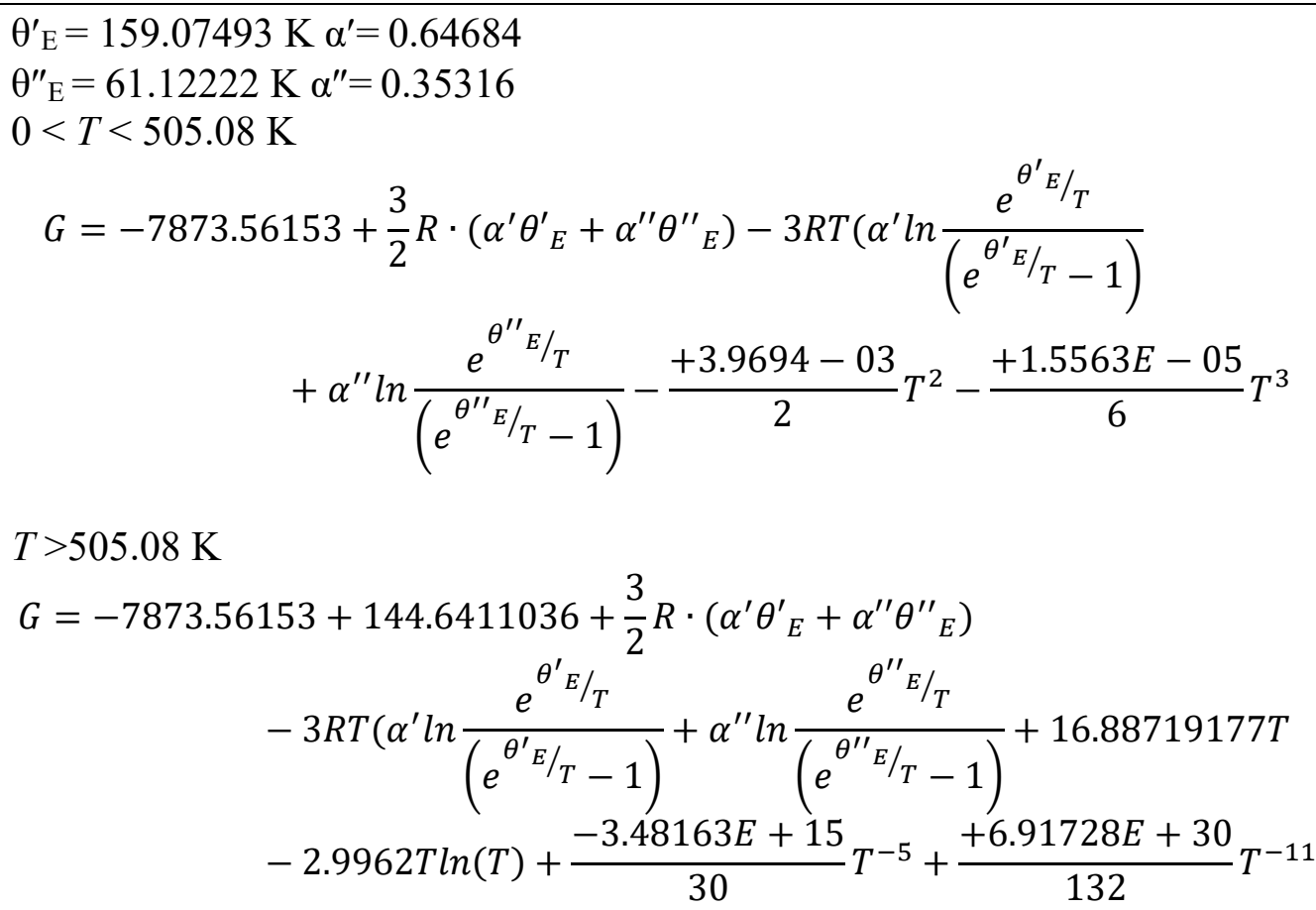 \\
\hline Liquid & $\begin{array}{l}\theta_{\mathrm{E}}=107.0238 \mathrm{~K} \\
\qquad \begin{array}{r}G=-3974.00518+\frac{3}{2} R \theta_{E}+3 R T \ln \frac{\left(e^{\theta_{E} / T}-1\right)}{e^{\theta_{E} / T}} \\
\Delta G_{\text {dif }}=G_{m}^{\text {trans }}-G_{m}^{\text {vib }}=7317.41566-18.3219791 T\end{array}\end{array}$ \\
\hline
\end{tabular}




\section{Summary}

A description of the thermodynamic data for pure tin was obtained using an extended Einstein model for the crystalline phases and a two state model for the liquid phase. During the assessment was concluded that more then one Einstein temperatures were needed to describe both the solid phases. So two possible variants were proposed, (a) with two Einstein temperature (sum of amplitude is equal to 1) and additional polynomial part, (b) with a variable number of Einstein functions (two or four) and arbitrary sum of parameters $a$.

During critical evaluation of the thermodynamic data it was concluded that there is lack of experimental values for the heat capacity of the solid phases. For this reason experimental investigations of the heat capacity for the $\beta$-tin were carried out in the temperature interval between 100 and $170 \mathrm{~K}$. Because the transformation from the white tin to grey tin is very difficult, particularly if the samples are pure, we used results from the ab-initio calculation in order to evaluate the model for the grey and white tin. The values of the entropy and enthalpy of transition at temperature of reversible phase transformation that we obtained are in good agreement with an estimation carried out based on the Voronin and Kutsenok method.

The question about the stability of the grey tin still remains open. This will be discussed in more detail in the Part II of the present work.

\section{Acknowledgements}

The of work of MISIS group on critical evaluation, SGTE assessment, enthalpy drop measurements and ab intio calculations was carried out with financial support from the Ministry of Education and Science of the Russian Federation in the framework of Increase Competitiveness Program of NUST «MISiS» (№K2-2018-010), implemented by a governmental decree dated $16^{\text {th }}$ of March 2013, N 211.

The work of group from MSU on adiabatic calorimetry and evaluation of $S^{o}{ }_{298.15}$ was carried in the framework of Program “Chemical Thermodynamics” (AAAA-A16-116061750195-2).

\section{Data availability statement}

The raw/processed data required to reproduce these findings cannot be shared at this time due to technical issues concerned with the web page. They will be later available to download from www.tmsrc.misis.ru 


\section{References}

[1] Chase M, Ansara I, Dinsdale A, Eriksson G, Grimvall G, Hoglund H, Yokokawa H. Group 1: heat capacity models for crystalline phases from $0 \mathrm{~K}$ to $6000 \mathrm{~K}$. Calphad 1995;19(4):437-447

[2] Grimvall G Thermophysical Properties of Materials. North Holland, Amsterdam, 1986.

[3] Khvan A.V, Dinsdale A.T., Uspenskaya I.A., Zhilin M., Babkina T., Phiri A.M. A thermodynamic description of data for pure $\mathrm{Pb}$ from $0 \mathrm{~K}$ using the two state model for the liquid phase. Calphad 2018;60:144-155.

[4] Voronin G.F., Kutsenok I.B. Universal Method for Approximating the Standard Thermodynamic Functions of Solids. J. Chem. Eng. Data 2013; 58:2083-2094

[5] http://td.chem.msu.ru/en/developments/cpfit/

[6] Dinsdale A.T., SGTE data for pure substances.Calphad 1991;15: 317-425.

[7] Agren J Thermodynamics of Supercooled liquids and their glass transition. J. Phys. Chem. Liq. 1988;18:123-139

[8] Agren J, Cheynet B, Clavaguera-Mora MT, Hack K, Hertz J, Sommer F, Kattner U. Group 2: Extrapolation of the Heat Capacity in Liquid and Amorphous Phases. Calphad 1995;19(4):449480

[9] Chen Q, Sundman B. Modeling of thermodynamic properties for BCC, FCC, liquid and amorphous iron, J. Phase Equilib. 2001; 22(6):631-644.

[10] Li Z, Bigdeli S, Mao H, Selleby M. Thermodynamic evaluation of pure Co for the third generation of thermodynamic databases. Physica Status Solidi B 2006; 254(2):1600231

[11] Bigdeli S, Ehteshami H, Chen Q, Selleby M. New description of metastable hcp phase for unaries Fe and Mn: Coupling between first-prinicples calculations and Calphad modelling. Physica Status Solidi B 2016; 253(9):1830-1836

[12] Bigdeli S, Mao H, Selleby M. On the third-generation Calphad databases: An updated description of Mn. Physica Status Solidi B 2015; 252(10):1-10

[13] Smith R The $\alpha$ (Semiconductor) $\leftrightarrow \beta$ (metal) transition in tin. J Less Common Met 1986;114:69-80

[14] McGlashan ML. The international Temperature Scale of 1990 (ITS-90). J. Chem. Thermodynamics 1990;22:653-663

[15] Hultgren R., Desai P.D., Hawkins D.T., Gleiser M., Kelley K.K., Wagman D.D., Selected Values of the Thermodynamic Properties of the Elements, American Society For Metals, Metals Park, Ohio, 1973.

[16] Stull DR, Sinke GC. Thermodynamic properties of the elements. Am. Chem. Soc. Adv. Chem. Series 18, 1956. 
[17] Corruccini RJ, Gniewek JJ. Specific Heats and Enthalpies of Technical Solids at Low

Temperatures. National Bureau of Standards Monograph 21, 1960

[18] Kelley KK, Contributions to the data on theoretical metallurgy. XIII High-Temperature Heat-Content, Heat Capacity, and Entropy Data for the Elements and Inorganic Compounds. US Dep Int. Bureau Mines 1960

[19] Cox J.D., Wagman D.D., Medvedev V.A. CODATA Key Values for Thermodynamics, Hemisphere Publishing Corp., New York, 1989

[20] Gurvich L.V., Veyts I.V., Medvedev V.A., Khachkuruzov G.A., Yungman V.S., Bergman G.A., Baybuz V.F., Iorish V.S., Yurkov G.N., Gorbov S.I., Nazarenko I.I., Dorofeyeva O.V., Kuratova L.F., Osina E.L., Gusarov A.V., Leonidov V.Ya., Przheval'skiy I.N., Rogatskiy A.L., Efremov Yu.M., Ryabova V.G.,. Zitserman V.Yu, Hayt Yu.G., Shenyavskaya E.A, Efimov M.E., Kulemza V.A., Khodeyev Yu.S., Tomberg S.E., Vdovin V.N., Yakobson A.Ya., Demidova M.S., in: Fourth edition,in: L.V. Gurvich, I.V. Veyts, C.B. Alcock (Eds.), Thermodynamic Properties of Individual Substances, 2, Hemisphere Publishing Corp., New York, 1991

[21] Brönsted JN. Studien zur chemischen Affinität. IX. Die allotrope Zinnumwandlung. Z. Phys. Chemie. 1914; 88U:479-489

[22] Rodebush WH. The atomc heats of cadmium and tin at low temperatures. J. Amer. Chem. Soc. $1923 ; 45: 1413-1416$

[23] Lange F. Untersuchungen über die spezifische Wärme bei tiefen Temperaturen. Z. Phys. Chem. Leipzig 1924;110:343-362

[24] Hill RW, Parkinson DH. XXV. The specific heats of germanium and grey tin at low temperatures Phil. Mag. 1952; (Series7) 43:338 :309-316

[25] Webb FG, Wilks J. The Measurement of Lattice Specific Heats at Low Temperatures Using a Heat Switch Proc. Roy. Soc. Chem. A 1955; 230: 549-559

[26] Keesom, W. H., and van den Ende, J. N. The specific heats of solids at temperatures obtainable with liquid helium. IV. The atomic heat of tin and zinc, Leiden Comm. 1932; 219b: $143-155$

[27] Corak WS, Satterthwaite CB. Atomic heats of normal and superconducting Tin between 1.2 and 4.5K. Phys. Rev. 1956; 102 (3):662-666

[28] Ramanathan KG, Srinivasan TM, A new vacuum calorimeter for low temperatures. Phil. Mag. 1955;46:338-340.

[29] Zavaritskii NV Investigation of the Thermal Properties of Superconductors NV Soviet Physics 1958 JETP_837-847

[30] Bryant CA. Low-temperature specific heat of indium and tin. Phys. Rev. 1961;123(2):491499. 
[31] O’Neal HR. Low-temperature heat capacities of indium and tin. Phys. Rev. A $1965 ; 137(3): 748-759$

[32] Cetas TC. Heat capacities from 1 to $30 \mathrm{~K}$ of $\mathrm{Zn}, \mathrm{Cd}, \mathrm{Sn}, \mathrm{Bi}$ and Y. Phys. Rev. 1969;182(3):679-685.

[33] Naumov VN, Nogteva VV, Paukov IE. Teploemkost, Entropiya Belogo Olova ( $\beta$-Sn) s interval 1.8-311K. J. Phys. Chem. 1978;2:497-498

[34] Keesom WH, Van Laar PH. Measurements of the atomic heats of tin in the superconductive and in the non-superconductive state. Physica 1938; 5(3):193-201.

[35] Yaqub M. Atomic Heats of Tin and Tin-indium. Cryogenics 1961; 1(3):166-170

[36] Kramer W, NöltingJ. Anomale spezifische wärmen und fehlordnung der metalle indium, zinn, blei, zink, antimony und aluminium. Acta Metall. 1972;20:1353-1359

[37] Klinghardt H. Messung von wahren spezifischen Wärmen bei hohen Temperaturen durch Heizung mit Glühelektronen. Ann. Phys. 1927;84:167-200

[38] Bartenev G.M. Teploemkost' legkikh metallov v tverdom I jidkom sostoyaniyakh. Zh. Techn. Fiz. 1947;17:1321-1324

[39] Richards JW. The Specific Heats of the Metals. J. Franklin Inst. 1893;136(1):37-53

[40] Stølen S, Grønvold F. Critical assessment of the enthalpy of fusion of metals used as enthalpy standards at moderate to high temepratures. Thermochimica Acta 1999;327:1-32.

[41] Wüst F, Meuthen A, Durrer R. Die Temperatur-Wärmeinhaltskurven der Technisch wichtigen Metalle. Berlin, Springer 1918.

[42] Jaeger FM, Bottema JA. The exact measurement of the Specific Heats of Solid Substances between 0 and 1625C. VI On the Law of Neumann-Joule-Kopp-Regnault concerning the Molecular Heat of Chemical Compounds in Function of the Atomic Heats. Proc. Roy. Acad. Amsterdam 1932;35:352-362.

[43] Iitaka I. On the Variation of the Specific Heat During Melting and the Heat of Fusion of Some Metals. Sceince Report of the Tohoku Imperial University. Series 1: Mathematics, Physics, Chemistry 1919;99-114

[44] Awbery JH, Griffiths E. The latent heat of fusion of some metals. Proc. Phys. Soc. London $1926 ; 38: 343-398$

[45] Umino S. On the Latent heat of fusion of Several Metals and their Specific Heats at High Temperatures. Sci. Rep. Tohoku Univ. 1926; 15: 597-617

[46] Genot M, Hagège R. Etude Thermodynamique du système étain-zinc. Compt Rend Acad Sci 1960;251:2901-2903

[47] Cohen E., van Eijk C. Physikalisch-chemische Studien am Zinn Z. Phys. Chem., Stöchiom. Verwandtschaftsl. 1899;30: 601-622 
[48] Heffan H. Heat Capacity of liquid tin. 1958. University of California, Berkeley.

[49] Yurchak R.P, Philippov LP. Teplovie svoystva zhidkikh olova i svinca. Teplophizika Vysokikh Temperatur. 1965;3:323-325.

[50] Chen HS, Turnbull D. The Specific heat of tin and gallium in their stable and undercooled pure liquid states. Acta Met. 1968;16:369-373.

[51] Feber RC, Herrick CC, Levinson LS. A calorimetric study of liquid silver and liquid tin. J. Chem. Thermodynamics 1969;1:169-175

[52] Irvine W. Experimental Determination of the Latent Heat of Spermaceti, Bees Wax. Tin, Bismuth, Lead, Zinc and Sulfur. Journal of Natural Philosophy, Chemistry and The Arts. Edited by Nicholson W. 1804; 9:45-52

[53] Pionchon M. Recherches calorimétriques sur les chaleurs spécifique et les changements d'état aux températures élevées. Ann Chimie Physique 1887;11:33-111.

[54] Richards JW. The Specific Heats of the Metals. J. Franklin Inst. 1893;136(3):178-192

[55] Bartenev GM. Teploti plavleniya olova, svintsa I evtektiki. Zh. Techn. Fiz. 1947;17(11):13251330.

[56] Oelsen W. Zur thermodynamischen Analyse III. Selbsttätige Aufzeichnung der

Wärmeinhaltskurven von Metallen und Legierungen. Archiv Eisenhüttenwessen 1955;26: 519522

[57] Chiotti P, Gartner GJ, Stevens ER, Yasutoshi Saito. Heats of Fusion and Transformation for Some Metals and Compounds. J. Chem. Engineering Data 1966;11(4):571-574

[58] Oelsen W, Oelsen O, Theil S. Präzisionsmessungen der Schmelzwärmen einiger Metalle. Z. Metllkde. 1955;48(8):555-560.

[59] Oelsen W, Reinskamp KH, Oelsen OO. Zur thermodynamischen Analyse. II. Die Wärmeinhaltskurve eines Stoffes aus einem einzigen kalorimetrischen Versuch. Achiv Eisenhüttenwessen 1955;26;253-266

[60] Nagasaki S, Fujita E. A study of the Phase Diagrams by the Specific Heat Measurements. Nippon Kinzoku Gak 1952;16:313-317

[61] Pascard R. Etude Par Analyse Thermoque des Transformations Allotropiques du Plonium. Acta Metall 1959; 7:305-318

[62] Reznitkiy LA, Kholler VA, Filippova SE. Differentsialniy microcalorimetr dlya provedeniya kolichestvennoy termographii. J. Phys. Chim. 1970;44(2):533-535

[63] Grønvold F. Enthalpy of fusion and temperature of fusion of indium, and redetermination of the enthalpy of fusion of tin. J. Chem. Thermodynamics 1993;25:1133-1144.

[64] Alpaut O, Heumann Th, Die Thermodynamische Daten der Festen Indium-Zinn-Legierungen. Acta Metall. 1965;13:543-548 
[65] Breuer K-H, Eysel W. The calorimetric calibration of differential scanning calorimetry cells. Thermochimica Acta 1982;57:317-329

[66] Höhne GWH, Breuer K-H, Eysel W. Differential Scanning Calorimetry: Comparison of Power Compensated and Heat Flux Instruments. Thermochimica Acta 1983; 69:145-151.

[67] Wolf G, Schmidt H-G, Bohmhammel K. Differential scanning calorimetry. A reliable method of enthalpy calibration. Thermochimica Acta 1994; 235:23-29

[68] Zahra CY, Zahra A-M. The Perkin-Elmer 1020 series thermal analysis system. Thermochimica Acta 1996;276:161-174.

[69] Rudberg F. Några föregående resultat af en undersökning om latenta värmet hos flytande Tenn och Bly, samt diverse flytande Metallegeringar. Kungl Vetensk Akad Handl 1829; 157175

[70] Person C.C. Recherches sur la chaleur latent. Compt Rend Hebdomadaires Séances Académie sciences 1846;23:162-163.

[71] Person C.C. Détermination de la chaleur totale des corps et du zero absolu. Ann. Chim. Phys. $1848 ; 24: 129-163$

[72] Spring W., Sur la chaleur des alliages de plomb et d'etain'. Bulletins de l'Academie royale des scineces, des lettres et des beaux-arts de Belgique 1886; 3(11) 355-405

[73] Robertson PW. Atomic and Molecular Heats of Fusion. J. Chem. Soc. Trans. 1902;81:12331243

[74] Guinchant JM Azotate d'argent. Calorimétrie à haute temperature. Comptes rendus hebdomadaires des sciences Academie des sciences 1907;145:320-322

[75] Schürmann E, Träger H. Die Empfindlichkeit und die Wiederholbarkeit von Messungen mit dem Kleinkalorimeter. Archiv für das Eisenhüttenwesen 1961;6:397-408

[76] Speros DM, Woodhouse RL. Quantitative Differential Thermal Analysis: Heats and Rates of Solid-Liquid Transitions. Nature; 1963; 197:1261-1263

[77] David DJ. Determination of Specific Heat and Heat of Fursion by Differential Thermal Analysis. Study of Theory and Operating Parameters. Anal. Chem; 1964; 36:2162-2166 [78] Gwinup P.D. Differential Scanning Calorimetry in High Temperature Chemistry. PhD Thesis, Oklahoma State University 1967.

[79] Kano M. Supercooling and Its Thermal Hysteresis of Pure Metal Liquids. Netsu Sokutei 1991; 18(2):64-70

[80] Natl. Inst. of Stand. and Tech. (U.S.) Standard Reference Material 2220. Temperature and Enthalpy of Fusion- Tin. Cited in Callnan JE, McDermott KM, Weir RD, Westrum EF.. Comparison of heat capacities measured by adiabatic calorimetry and by scanning calorimetry: 
thermodynamic properties of 9-methylcarbazole at temperatures between $4 \mathrm{~K}$ and $345 \mathrm{~K}$. J. Chem. Thermodynamics 1992;24:233-243.

[81] Callanan JE. Cited in Callnan JE, McDermott KM, Weir RD, Westrum EF. Comparison of heat capacities measured by adiabatic calorimetry and by scanning calorimetry: thermodynamic properties of 9-methylcarbazole at temperatures between $4 \mathrm{~K}$ and $345 \mathrm{~K}$. J. Chem. Thermodynamics 1992;24:233-243.

[82] Varushchenko R.M., Druzhinina A.I., Sorkin E.L. Low-temperature heat capacity of 1bromoperfluorooctane. J. Chem. Thermodyn 1997; 29: 623-637.

[83] Varushchenko R.M., Druzhinina A.I.. Determination of Saturated Vapor Pressure of Organic Substances from the Triple to Critical Point. High Temp 2010; 48: 328-335.

[84] Preston-Thomas H. The International Temperature Scale of 1990 (ITS90) Metrologia 1990; 27(1): 3-10.

[85] Kresse G., J. Hafner J. Ab initio molecular dynamics for liquid metalsю Phys. Rev. B1993; 47 (1):558-561.

[86] Kresse G., J. Hafner J. Ab initio molecular-dynamics simulation of the liquid-metalamorphous-semiconductor transition in germanium. Phys. Rev. B 1994; 49:14251-14269.

[87] Kresse G., Furthmuller J. Efficiency of ab-initio total energy calculations for metals and semiconductors using a plane-wave basis set, Comput. Mater. Sci.1996; 6: 15-50.

[88] Kresse G., Furthmuller J. Efficient iterative schemes for ab initio total energy calculations using a plane-wave basis set, Phys. Rev. B 1996; 54 (16):11169-11186.

[89] Kresse G., Joubert D. From ultrasoft pseudopotentials to the projector augmented-wave method, Phys. Rev. B 1999;59 (3):1758-1775.

[90] Blöchl P.E., Projector augmented-wave method. Phys. Rev. B1994;50:.17953-17979.

[91] Ceperley D. M., Alder B. J., Ground State of the Electron Gas by a Stochastic Method. Phys. Rev. Lett 1980; 45:566-569.

[92] Methfessel M., Paxton A. T. High-precision sampling for Brillouin-zone integration in metals. Phys. Rev. B 1989; 40: 3616-3621.

[93] Togo A., Tanaka I., First principles phonon calculations in materials science, Scr. Mater.2015; 108:1-5.

[94] Khvan A.V, Syzdykova A, Belov M, Babkina T, Cheverikin V.V., Uspenskaya I.A, Abrikosov IA, Dinsdale A.T. Thermodynamic properties of tin: Part II On thermodynamic data of a grey tin, grey tin stability and $\alpha \rightarrow \beta$ transition. To be submitted to Calphad 2019.

[95] Dinsdale A.T. Thermodynamic description for pure Si and Ge in solid and liquid state from 0K. Calphad 2019 To be submitted for publication 


\section{Figure Captures}

Figure 1 - Comparison of heat capacity calculated from assessed datasets: a) grey tin; b,c) white tin; d) Liquid tin. Please note that the curves are drawn from the values tabulated by the assessors and are therefore smooth.

Figure 2 - Experimental heat capacity data for $\alpha$-tin: a) 0-300 K; b) 0-50 K

Figure 3 - Experimental heat capacity data for $\beta$-tin: a) $0-5 \mathrm{~K}$; b) $0-50 \mathrm{~K}$; c) $50-300 \mathrm{~K}$; d) 200 $500 \mathrm{~K}$.

Figure 4 Enthalpy increments measurements for $\beta$-tin a) $H^{\circ}(T)-H^{\circ}(273)$; b) $H^{\circ}(T)-H^{\circ}(293)$

Figure 5 - Experimental heat capacity data for liquid tin

Figure 6 - Enthalpy increments measurements for liquid tin $H^{\circ}(T)-H^{\circ}(293)$ (Data from Feber et al. [51] are for $H^{\mathrm{o}}(T)-H^{\mathrm{o}}(298)$

Figure 7 - Comparison of adiabatic calorimetry results with measurements from various scientific groups

Figure 8- Experimental results of the enthalpy drop measurements of the liquid tin in comparison with existing experimental literature values. Experimental uncertainties of $H(T)-H(298)$ values in our experiments are comparable with the size of symbols

Figure 9 - Experimental and ab-initio data of the heat capacity for $\alpha$-tin for the temperature range: $0-300 \mathrm{~K}$.

Figure 10 - Experimental and ab-initio data of the heat capacity for $\beta$-tin for the temperature range $0-300 \mathrm{~K}$.

Figure 11 - Comparison of experimental and calculated data for $\alpha$-tin

Figure 12 - Calculated heat capacity for the solid $\alpha$-tin

Figure13. Calculated heat capacity for the solid $\beta$-tin a) whole temperature interval; b) $0-100 \mathrm{~K}$; c) $100-500 \mathrm{~K}$.

Figure 14 - Calculated $H^{\mathrm{o}}(T)-H^{\mathrm{o}}(293)(\mathrm{a}), H^{\mathrm{o}}(T)-H^{\mathrm{o}}(273)(\mathrm{b}), H^{\mathrm{o}}(T)-H^{\mathrm{o}}(471)(\mathrm{c})$ and in comparison with experimental values

Figure 15 - a) Calculated heat capacity in comparison with the experimental data from the literature $[48,50,55]$; b) calculated enthalpy increments for the liquid phase in comparison with literature data $[43-45,51]$ and experiments undertaken in the present work; c) calculated enthalpy increments for the liquid phase in comparison with data from Genot [46]

Figure $16-\chi$ fraction of translational atoms and $1-\chi$ fraction of vibrational atoms Figure 17 - Calculated heat capacity curve for pure tin. 